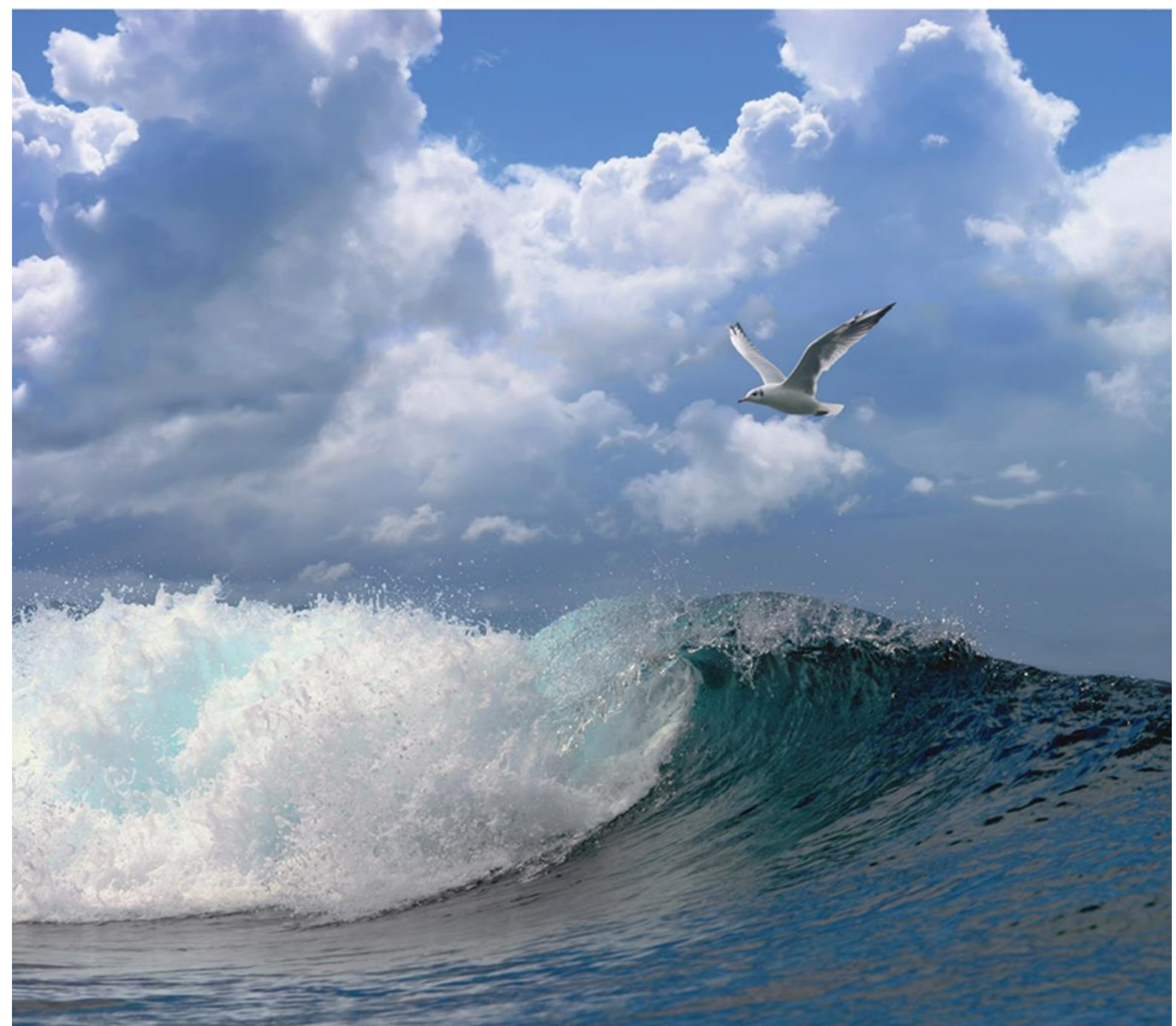

\title{
Quickscan impact van visserij en opties voor begrenzing van een oesterbank in de Voordelta
}




\section{Quickscan impact van visserij en opties voor begrenzing van een oesterbank in de Voordelta}

Auteur(s): $\quad$ Oscar Bos, Jacqueline Tamis, Ruud Jongbloed

Dit onderzoek is uitgevoerd door Wageningen Marine Research en gesubsidieerd door het Ministerie van Landbouw, Natuur en Voedselkwaliteit, in het kader van het Beleidsondersteunend onderzoekthema 'Duurzame Noordzee' (projectnummer Kennisdesk BO-43-116.01-000) 
Keywords: Ostrea edulis, platte oester, visserij

Opdrachtgever: Ministerie van LNV

T.a.v.: E. Knegtering

Postbus 20401

2500 EK Den Haag

BO-43-116.01-000

Dit rapport is gratis te downloaden van https://doi.org/10.18174/545157.

Wageningen Marine Research verstrekt geen gedrukte exemplaren van rapporten.

Wageningen Marine Research is ISO 9001:2015 gecertificeerd.

\section{(C) Wageningen Marine Research}

Wageningen Marine Research, instituut binnen de rechtspersoon Stichting

Wageningen Research, hierbij

vertegenwoordigd door

Dr.ir. J.T. Dijkman, Managing director

KvK nr. 09098104,

WMR BTW nr. NL 8113.83.696.B16.

Code BIC/SWIFT address: RABONL2U

IBAN code: NL 73 RABO 0373599285
Wageningen Marine Research aanvaardt geen aansprakelijkheid voor gevolgschade, noch voor schade welke voortvloeit uit toepassingen van de resultaten van werkzaamheden of andere gegevens verkregen van Wageningen Marine Research. Opdrachtgever vrijwaart Wageningen Marine Research van aanspraken van derden in verband met deze toepassing. Alle rechten voorbehouden. Niets uit deze uitgave mag weergegeven en/of gepubliceerd worden, gefotokopieerd of op enige andere manier gebruikt worden zonder schriftelijke toestemming van de uitgever of auteur. 


\section{Inhoud}

$\begin{array}{lr}\text { Samenvatting } & 4\end{array}$

$\begin{array}{llr}1 & \text { Inleiding } & 5\end{array}$

$\begin{array}{lll}1.1 & \text { Achtergrond } & 5\end{array}$

1.2 Visserij 6

$\begin{array}{lll}1.3 & \text { Kennisvragen } & 8\end{array}$

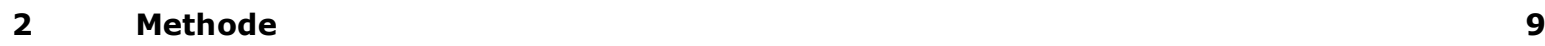

$\begin{array}{llr}2.1 & \text { Locatie } & 9\end{array}$

$\begin{array}{lll}2.2 & \text { Effect visserij } & 10\end{array}$

$\begin{array}{ll}\text { 2.2.1 Definitie visserijvormen } & 10\end{array}$

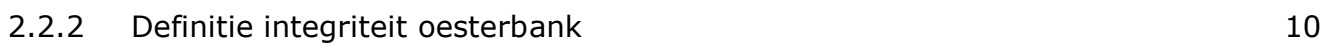

$\begin{array}{ll}2.2 .3 \text { Beoordeling effect } & 11\end{array}$

$\begin{array}{lll}2.3 & \text { Begrenzing platteoesterbank } & 12\end{array}$

$\begin{array}{ll}\text { 2.3.1 Bufferzones } & 12\end{array}$

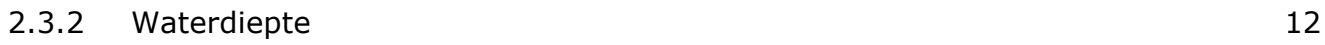

$\begin{array}{ll}\text { 2.3.3 Polygonen oesterbank } & 13\end{array}$

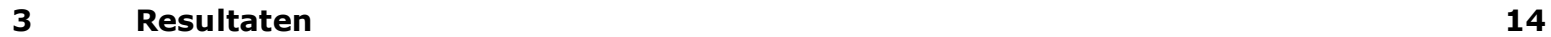

$\begin{array}{lll}3.1 & \text { Effecten van visserij } & 14\end{array}$

3.1.1 Bodemberoerende visserij (TBB, DRB, OTB, HMD) 14

$\begin{array}{lll}3.1 .2 & \text { Visserij met vaste vistuigen } & 15\end{array}$

$\begin{array}{ll}3.1 .3 & \text { Mosselzaadinvanginstallaties (MZI's) } \\ \end{array}$

$\begin{array}{llr}3.2 & \text { Begrenzing } & 18\end{array}$

$4 \quad$ Conclusies en aanbevelingen $r 22$

$\begin{array}{llr}4.1 & \text { Effecten van visserij } & 22\end{array}$

4.1.1 Aanbevelingen $\quad 23$

$\begin{array}{lll}4.2 & \text { Begrenzing } & 24\end{array}$

$\begin{array}{llr}5 & \text { Kwaliteitsborging } & 25\end{array}$

$\begin{array}{lr}\text { Literatuur } & 26\end{array}$

$\begin{array}{lr}\text { Verantwoording } & 29\end{array}$ 


\section{Samenvatting}

Platte oesters (Ostrea edulis) vormen riffen met een grote biodiversiteit. In 2015 werd in de Voordelta bij de Brouwerdam een wilde bank (ca 40 ha) ontdekt, bestaande uit platte oesters en andere schelpdieren en begroeid met diverse andere soorten. Onder OSPAR en de Habitatrichtlijn kwalificeren oesterbanken als te beschermen habitat, maar op dit moment is het rif in de Voordelta nog niet beschermd.

Om de oesterbank beter in beeld te brengen -in aanloop naar mogelijke verdere bescherming- wordt het als onderzoeksgebied aangemerkt (2021-2024), waarvoor visserijmaatregelen zullen worden ingesteld. Daarbij zullen de leeftijdsopbouw, overleving en reproductie van platte oesters in kaart worden gebracht evenals de geassocieerde biodiversiteit.

De eerste kennisvraag is welke visserijvormen mogelijk schade zouden kunnen veroorzaken aan benthos/hardsubstraatbewonende organismen, inclusief oesters. Deze vraag is beantwoord met behulp van literatuuronderzoek, aangevuld met expert judgement en een gesprek met de enige visser die in het gebied actief is. Hierbij is uitgegaan van het voorzorgprincipe. De tweede vraag is welke begrenzing rondom het rif gehanteerd zou kunnen worden als visserijmaatregel.

Bodemberoerende visserijvormen, zoals garnalenvisserij, zullen het rif zeker aantasten. Voor passieve visserijvormen zoals kooien, korven en staand want, zijn de fysieke effecten op benthos/hardsubstraatbewonende organismen, waarschijnlijk klein of afwezig. Wel kan specifieke visserij op kreeften en krabben zorgen voor een verstoring van de benthische biodiversiteit. Niet alle vergunde visserijvormen komen ook daadwerkelijk bij de oesterbank voor. De enige gebruikte vorm is het GNC-tuig (kieuwnet (omringend); gillnets (circling)) voor visserij op zeebaars en harders, die de oesterbank waarschijnlijk niet aantast. Om inzicht te krijgen in het bodemcontact van het net adviseren we een kleine proef uit te voeren met camera's.

Als visserijmaatregel voor bodemberoerende visserij worden drie bufferzones voorgesteld, gebaseerd op de dimensies van de vistuigen en methodes zoals gebruikt in de garnalenvisserij. De minimale bufferzone is $43 \mathrm{~m}$ rondom het oesterbank. Ervan uitgaande dat het rif zich mogelijk nog zal uitbreiden in de toekomst, stellen we ook bufferzones van 50 en 100 m voor. 


\section{$1 \quad$ Inleiding}

\section{$1.1 \quad$ Achtergrond}

Platte oesters (Ostrea edulis) vormen riffen die vanwege hun biodiversiteit beschermd worden. Onder de EU-Habitatrichtlijn kunnen oesterbanken als biogene riffen in $\mathrm{H} 1170$ (riffen) beschermd worden. Onder het OSPAR-verdrag is de platte oester aangemerkt als bedreigde soort en habitat (OSPAR Commission 2008) en is er een aanbeveling aangenomen over bescherming en/of herstel van de platte oester voor onder meer OSPAR-regio II (i.e. Greater North Sea) (OSPAR Commission, 2013; Bos \& Tamis, 2020). Verder heeft Nederland onder de Europese Kaderrichtlijn Mariene Strategie (KRM) voor de descriptor "zeebodemintegriteit" onder meer het volgende milieudoel opgenomen: D6T5: de terugkeer en het herstel van biogene riffen, waaronder platteoesterbanken (Min IenW en Min LNV, 2018).

In 2015 werd in het Natura 2000-gebied Voordelta, aan de Noordzeekant van de Brouwersdam, een 13,5 ha grote bank van platte oesters (Ostrea edulis) gevonden (Kamermans et al. 2015), in combinatie met andere schelpdieren. Verder onderzoek liet zien dat de bank ca. 40 ha groot was (Sas et al. 2018, Christianen et al, 2019.). Sindsdien vindt in het gebied onder meer onderzoek plaats naar herstel van de platte oester (Sas et al., 2016, 2018, 2019; Didderen et al., 2019; Van der Have 2019).

Leeftijdsonderzoek laat zien dat het oudste exemplaar zich mogelijk al gevestigd moeten hebben in de periode 2001-2002 (Witbaard et al., 2020). Verder waren van de in 2015 verzamelde exemplaren er waarschijnlijk twee ouder dan 7 jaar en van die uit 2017, drie ouder dan 9 jaar. Dat betekent dat de oesterbank al voor 2008, toen de Voordelta als Natura 2000-gebied werd aangewezen, in bepaalde mate aanwezig moet zijn geweest.

De bank is mogelijk ontstaan sinds in 1998 een sluis in de Brouwersdam jaarrond openging en o.a. platteoesterlarven vanuit de Grevelingen zich konden vestigen in de Voordelta (Christianen et al. 2018; Sas et al. 2019). De oesterbank ligt in een gebied waar - in elk geval in geanalyseerde perioden voor 2015 - er een relatieve lage visserijintensiteit was (Kamermans et al. 2015, Min. IenM, RWS Zee en Delta, 2016).

De Minister van LNV heeft eind 2020 aangegeven te kijken of bescherming van onder meer de oesterbank in de Voordelta kan meelopen in de wijziging van de Uitvoeringsregeling visserij die per 1 april 2021 in moet gaan (Vaste commissie voor LNV, 2020).

LNV neemt zich voor om het onderzoeksgebied te sluiten voor visserijvormen die schadelijk kunnen zijn voor het in integere toestand kunnen onderzoeken van de platteoesterpopulatie en de oesterbank. In het grotere gebied waarbinnen zich de oesterbank bevindt, mogen verschillende visserijvormen worden uitgeoefend. De vraag is in hoeverre deze visserijvormen de integriteit van de oesterbank en de platteoesterpopulatie en daarmee het voorgenomen onderzoek kunnen schaden. In dit rapport is een quickscan gemaakt van de aanwezige visserijvormen welk effect ze zouden kunnen hebben op de integriteit van de oesterbank. 


\subsection{Visserij}

In de Voordelta zijn drie typen visserijen te onderscheiden (Rijnsdorp et al., 2006; Poot et al., 2006):

A. bodemberoerende visserij (boomkorvisserij, garnalenvisserij, bordenvisserij)

De voornaamste vorm van visserij in de Voordelta, de boomkorvisserij op platvis (Tabel 1), is in het bodembeschermingsgebied (zie Figuur 1) niet toegestaan. De garnalenvisserij is er wel toegestaan. Er zijn nog diverse garnalenvissers actief op basis van door LNV verleende Nb-wet-/Wnb-vergunningen.

Schelpdiervisserij vindt vooral plaats op Ensis sp. Er zijn voor dat gebied ook vier vergunninghouders bekend voor Ensis-visserij (bron: LNV). Er heeft geen visserij op kokkels plaatsgevonden de afgelopen jaren, omdat deze soort nauwelijks aanwezig was (Troost et al., 2021). Visserij op Spisula is niet toegestaan (Tabel 2).

B: visserij met vaste vistuigen (korven, fuiken, staand want)

De visserij met vaste vistuigen (borden-, fuiken-, staand want en zegenvisserij) is kleinschalig in de Voordelta. In het visserijgebied Brouwerhavense Gat (Figuur 1) zijn 2 staandwantvissers, 2 zegenvissers en 21 standaardvergunningshouders bekend eind 2020 (bron: RVO) (Tabel 3). De zegenvisser die bij oesterbank vist, vist niet met een zegen, maar met een GNC (kieuwnet (omringend); gillnet (circling)). De verkeerde codering is een administratieve kwestie. 
Tabel 1. Visserijvormen en doelsoorten in de Voordelta in 2006 (Rijnsdorp et al., 2006).

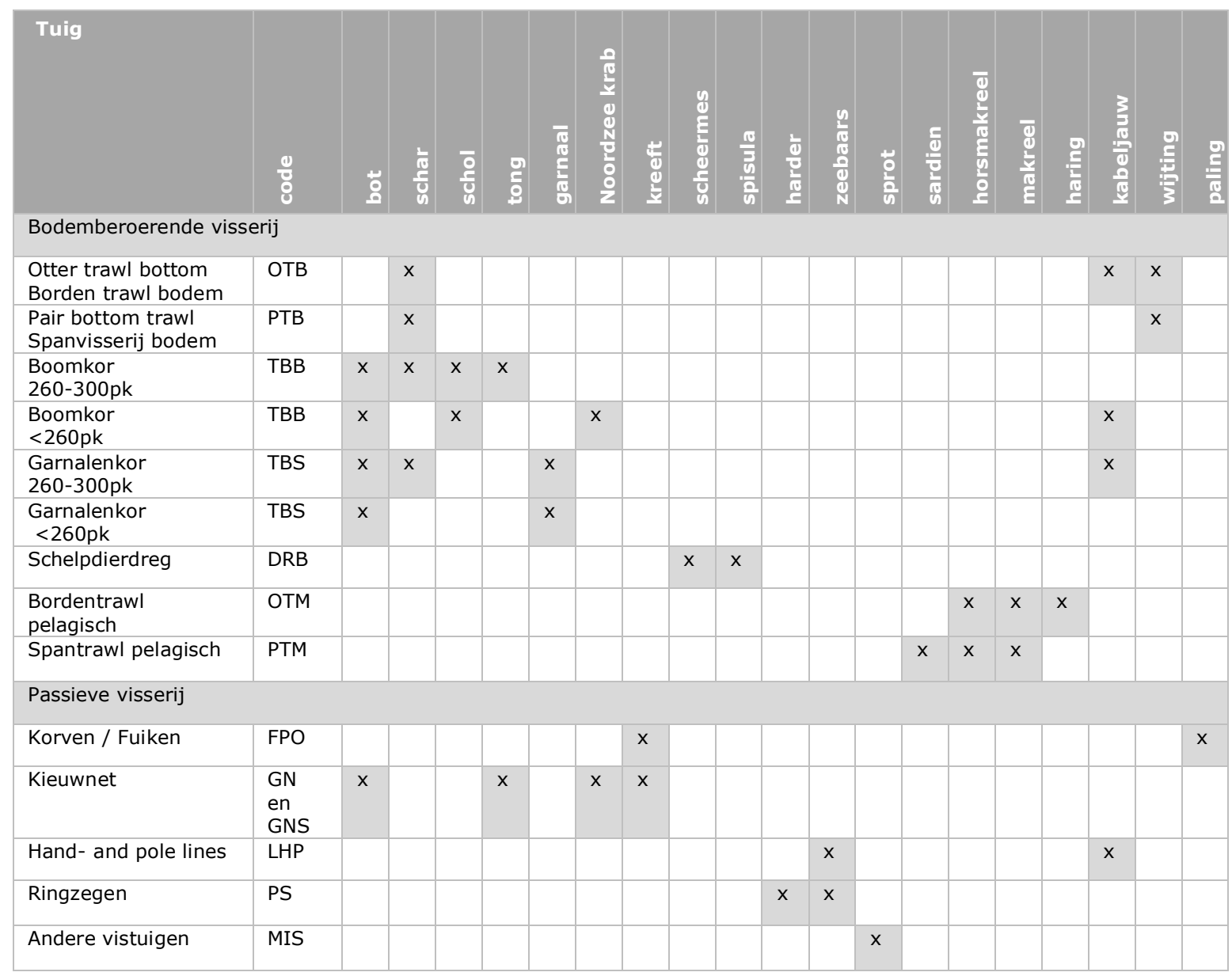

\section{B. overige vormen van visserij.}

Het aantal mosselzaadinvanginstallaties (mzi's) is de afgelopen jaren, zoals verwacht, toegenomen in de rest van de Voordelta. In het visserijgebied Brouwershavense Gat ligt een perceel waar jaarlijks in het voorjaar mzi's worden geplaatst die tot in het najaar worden geoogst.

Tabel 2. Visserijvormen binnen het bodembeschermingsgebied en rustgebied Bollen van de Ooster van Natura 2000-gebied Voordelta (Min. IenM, RWS Zee en Delta, 2016). Voor details over de beperkingen en voorwaarden: zie beheerplan.

\begin{tabular}{|c|c|c|c|}
\hline & Activiteit & $\begin{array}{l}\text { Toegestaan in het } \\
\text { bodembeschermingsgebied? }\end{array}$ & $\begin{array}{l}\text { Toegestaan in } \\
\text { rustgebied } \\
\text { Bollen van de } \\
\text { Ooster? }\end{array}$ \\
\hline \multirow[t]{5}{*}{ A } & Bodemberoerende visserij & & \\
\hline & boomkorvisserij groter dan 260 pk (191 kW) & nee & nee \\
\hline & sleepnetvisserij kleiner dan 260 pk (191 kW) & beperkt & nee \\
\hline & bordenvisserij (anders dan op garnalen) & beperkt & nee \\
\hline & schelpdiervisserij & $\begin{array}{l}\text { ja } \\
\text { Spisula-visserij in gehele } \\
\text { Voordelta niet toegestaan } \\
\text { gedurende looptijd beheerplan. }\end{array}$ & nee \\
\hline \multirow[t]{2}{*}{$\mathrm{C}$} & Overige vormeen & & \\
\hline & mosselzaadinvanginstallaties & ja & nee \\
\hline
\end{tabular}


Tabel 3. Aantallen bij RVO bekende vergunninghouders in het visserijgebied Brouwershavense Gat (daarbij mogen de vergunninghouders van het gehele Brouwershavense Gat (en de overige bij de onderscheiden groepen vergunninghouders vermelde gebieden) gebruik maken) (bron: RVO, via E. Knegtering, LNV).

\begin{tabular}{ll} 
Vergunninghouders & Waar en hoe toegestaan? \\
2 staandwantvissers & $\begin{array}{l}\text { max. } 5000 \text { meter staand want in het Zeegat van Goeree en } \\
\text { Brouwershavense Gat en max. 3500 meter staand want in het } \\
\text { Brouwershavense Gat (gereserveerd) }\end{array}$ \\
\hline 2 zegenvissers & $\begin{array}{l}\text { max. } 1500 \text { meter zegen in de Oosterschelde, Westerschelde, Zeegat van } \\
\text { Goeree en Brouwershavense Gat }\end{array}$ \\
\hline $\begin{array}{l}21 \text { standaardvergunning- } \\
\text { houders (schietfuiken/ kubben/ } \\
\text { korven en ankerkuil) }\end{array}$ & $\begin{array}{l}\text { max. } 180 \text { schietfuiken/ kubben/ korven en een ankerkuil in de } \\
\text { Westerschelde, het Zeegat van Goeree en het Brouwershavense Gat }\end{array}$ \\
\hline
\end{tabular}

\subsection{Kennisvragen}

Het ministerie van LNV stelt de volgende kennisvragen:

1. Visserij: Welke visserijvormen zijn niet verenigbaar met het zich gedurende vier jaar in integere toestand kunnen ontwikkelen van de platteoesterpopulatie en de oesterbank in de Voordelta (inclusief begeleidende biodiversiteit, met een focus op benthos en hardsubstraatbewonende soorten) in het bodembeschermingsgebied van het Natura 2000 gebied Voordelta dan wel het visserijgebied Brouwershavense Gat, en daarmee ook niet met het door WMR voorgenomen onderzoek van die ontwikkeling? Daarbij gaat het in het bijzonder om:

- $\quad$ sleepnetvisserij kleiner dan 260 pk (191 kW);

- garnalenvisserij (anders dan sleepnetvisserij) kleiner dan 260 pk (191 kW));

- bordenvisserij (anders dan op garnalen);

- $\quad$ schelpdiervisserij (met inbegrip van Ensis-visserij en uitgezonderd visserij op Spisula subtruncata (halfgeknotte strandschelp) (niet toegestaan);

- $\quad$ visserij met korven en fuiken (schietfuiken/ kubben/ korven)

- $\quad$ ankerkuilvisserij

- $\quad$ staandwantvisserij (o.a. kieuwnetten of warnetten)

- zegenvisserij

- mosselzaadinvanginstallaties

2. Begrenzing: Hoe zou de begrenzing van het te sluiten gebied eruit moeten zien? 


\section{Methode}

\section{$2.1 \quad$ Locatie}

Binnen het Natura 2000-gebied Voordelta (Figuur 1; groen) ligt het bodembeschermingsgebied Voordelta (oranje begrenzing) met daarbinnen het visserijgebied Brouwerhavense Gat (grijs gestreepte begrenzing). De oesterbank (paars) ligt ten oosten van de zandplaat Bollen van de Ooster (grijs gearceerd), een rustgebied voor zeehonden en een aantal vogelsoorten (Min EZ, 2016).

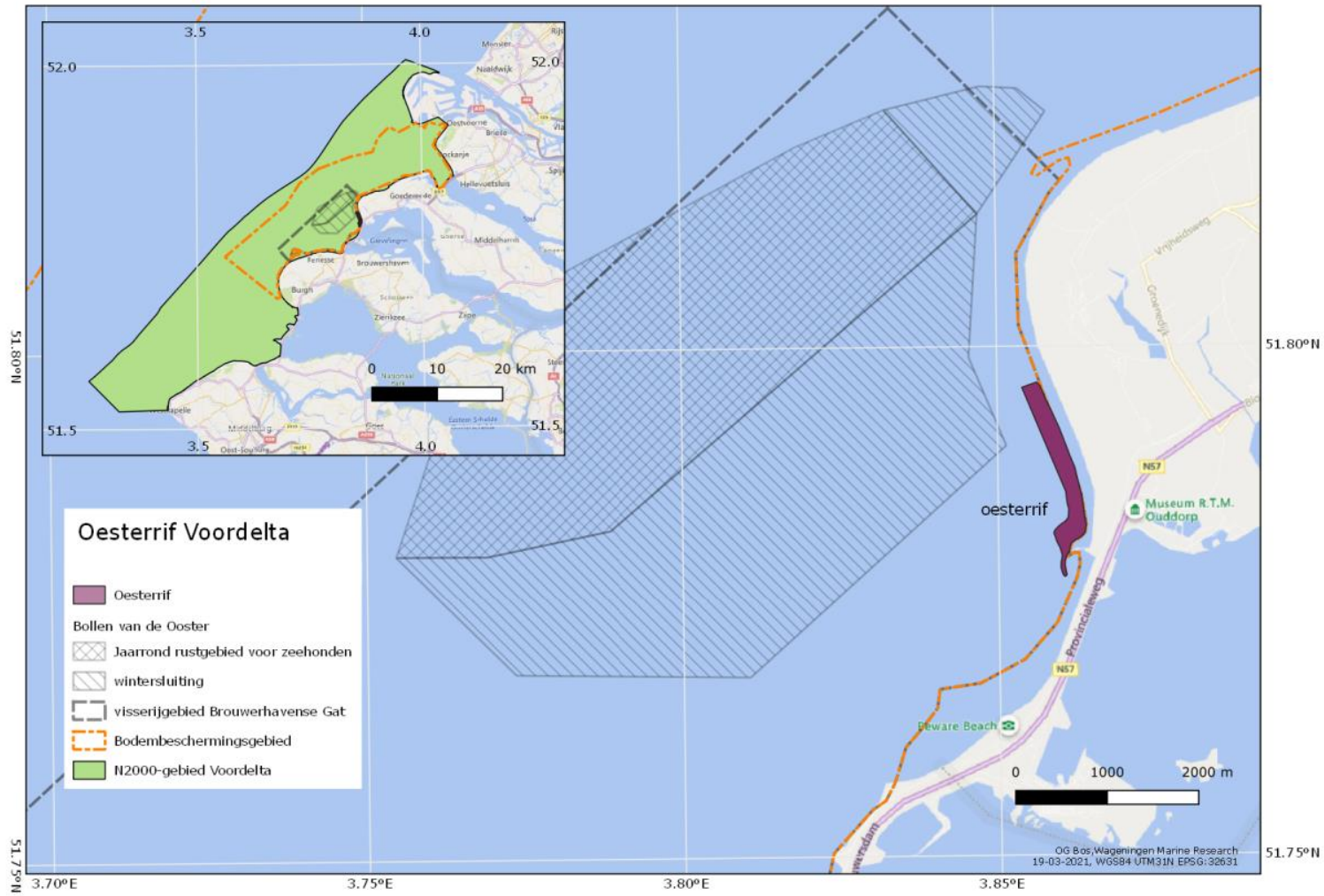

Figuur 1. Natura 2000-gebied Voordelta met daarbinnen het bodembeschermingsgebied, het visserijgebied Brouwerhavense Gat, de Bollen van de Ooster en de oesterbank in de Voordelta. Kaart: Oscar Bos, Wageningen Marine Research. Bron visserijgebied: https://wetten.overheid.nl/BWBR0002703/1994-06-29; bodembeschermingsgebied: LNV (2008); coördinaten oesterbank: Christianen et al. (2018). 


\subsection{Effect visserij}

\subsubsection{Definitie visserijvormen}

Tabel 4. Overzicht typen visserij, bijbehorende vistuigen en codes (bron: Rijnsdorp et al., 2006, LNV pers. com)

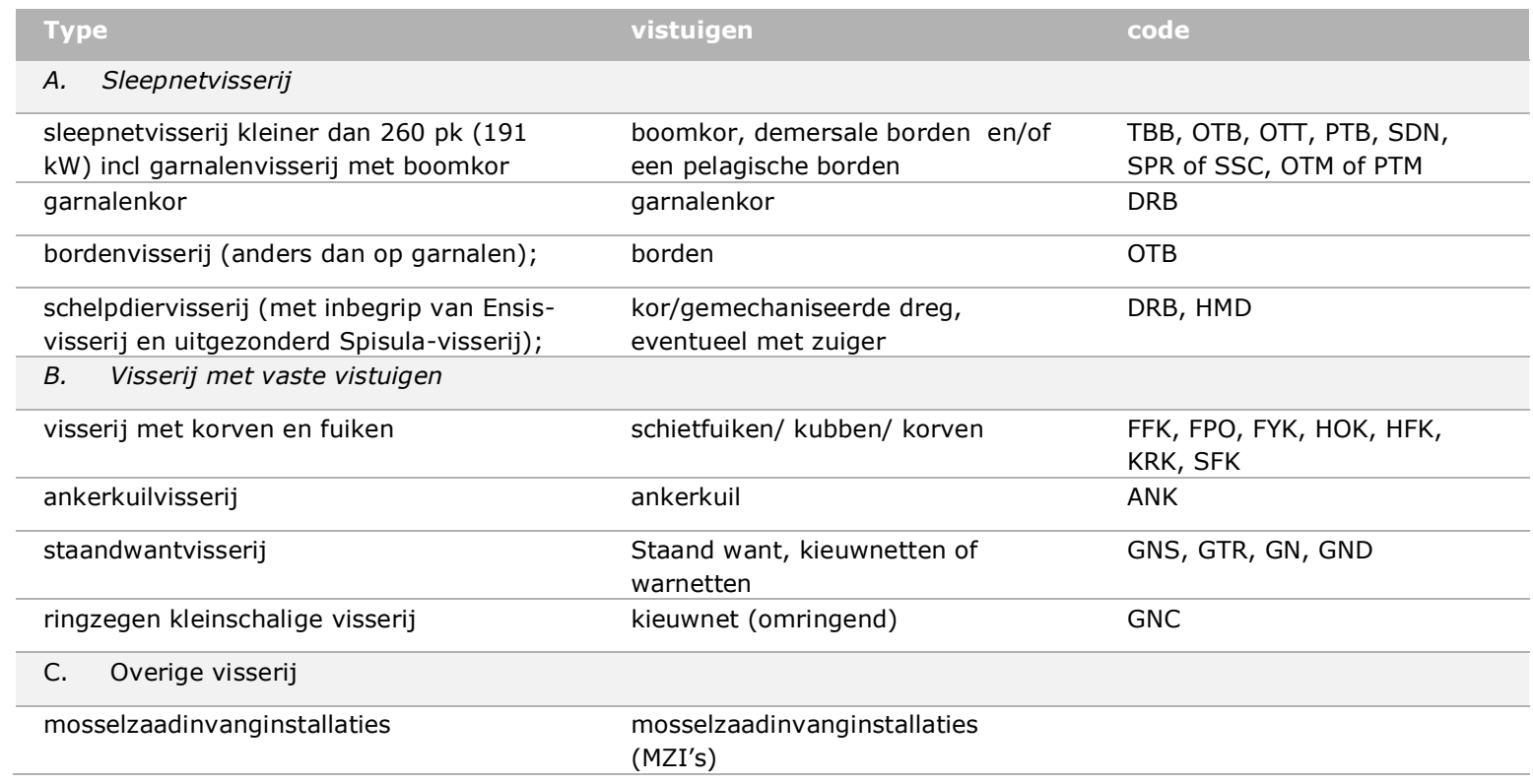

\subsubsection{Definitie integriteit oesterbank}

Een oesterbank bestaat uit oesters en geassocieerde biodiversiteit die op de zandbodem of op hard substraat voorkomen. Een activiteit wordt in dit rapport als verstorend voor de integriteit van een oesterbank beschouwd, als er sprake is van verwijdering of beschadiging van de oesters en geassocieerde biodiversiteit. Dit staat los van de vraag of de visserijverstoring groter of kleiner is dan de natuurlijke verstoring door golfwerking of stroming.

Onder geassocieerde biodiversiteit van een oesterbank wordt in dit rapport verstaan de soorten die zich vestigen op en rondom oesterbanken (sponzen, zacht koraal, zakpijpen, etc), of die er gebruik van maken als schuilplaats (krabben, kreeften), foerageerlocatie, of als opgroeigebied. Het gaat hierbij niet om soorten die wel in het gebied voorkomen maar geen specifiek onderdeel uitmaken van de biodiversiteit van een oesterbank, zoals pelagische vissen (haring, sprot), vissoorten geassocieerd met zandige bodems (schol, tong), zeezoogdieren en vogels.

Bij de analyse van de impact van visserij op de oesterbank gaat het alleen om effecten op de platte oesters, de - gemengde - oesterbank en de geassocieerde biodiversiteit, en niet om de overige soorten. 


\subsubsection{Beoordeling effect}

Per type visserij is onderzocht wat de mogelijke effecten zijn op benthos/hardsubstraatbewonende organismen, inclusief oesters. Deze vraag is beantwoord met behulp van literatuuronderzoek, aangevuld met expert judgement en een gesprek met de enige visser die in het gebied actief is. Hierbij is uitgegaan van het voorzorgprincipe. De beoordeling van de mogelijke effecten is als volgt:

- Rood: groot effect op het oesterbank. Dit geldt voor visserijvormen die actief door/over de bodem vissen, waarbij de bodem zeker geraakt wordt.

- Oranje: klein effect op het oesterbank. Dit geldt voor passieve visserijvormen, waarbij onderdelen van het net, of het anker, in principe op een vaste plek staan, maar onder invloed van stroming en golven, of tijdens het ophalen door of over de bodem kunnen schuren.

- Geel: klein/geen effect op het oesterbank. Dit geldt voor visserijvormen die pelagisch vissen, of nauwelijks/geen bodemcontact hebben.

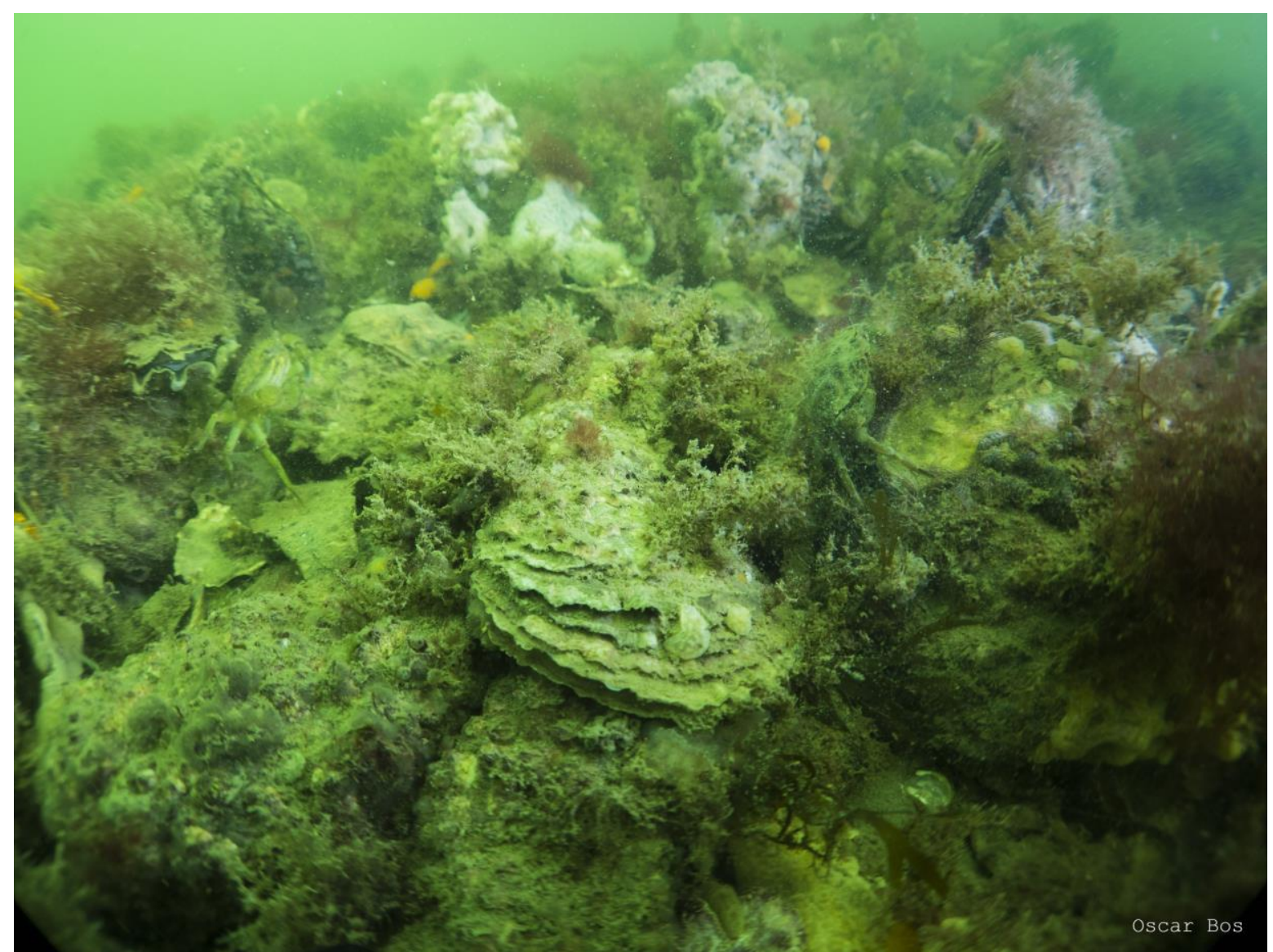

Figuur 2. Platte oester (Ostrea edulis) (midden) en Japanse oester (Maggalana gigas) (achtergrond) en geassocieerde biodiversiteit bij de oesterbank nabij de Brouwersdam (foto: Oscar Bos/WMR). 


\subsection{Begrenzing platteoesterbank}

\subsubsection{Bufferzones}

Bufferzones zijn onderdeel van technische visserijmaatregelen binnen de EU om kwetsbare habitats te beschermen. Een bufferzone kan worden berekend op basis van waterdiepte, de lengte van de vislijn en de lengte van het vistuig (N2K group, 2018). Uitgangspunt is dat een vistuig de beschermde habitat niet kan beschadigen, doordat het vistuig en de habitat voldoende ruimtelijk gescheiden zijn. Garnalenvisserij lijkt de belangrijkste visserij met sleepnetten te zijn in het gebied (Tabel 2). Daarom is voor die visserij uitgerekend wat de bufferzone zou moeten zijn.

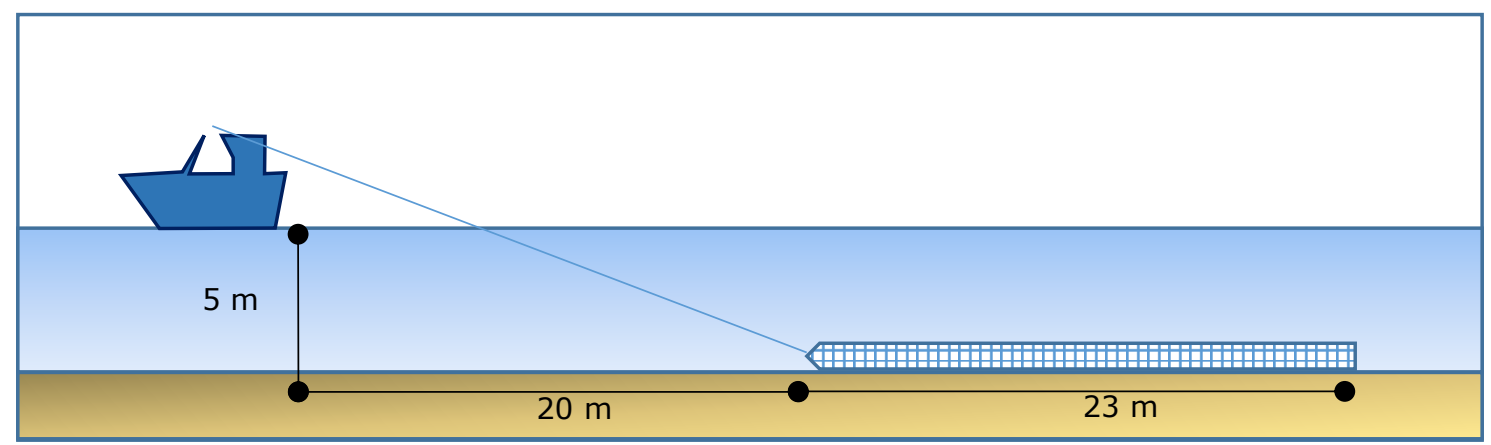

Figuur 3. Berekening breedte bufferzone.

Om een bufferzone voor de garnalenvisserij uit te rekenen is het uitgangspunt dat de gezamenlijke lengte van vislijn en visnet achter het schip een maat is voor de minimale bufferzone. Er is uitgegaan van de volgende parameters: een waterdiepte van $5 \mathrm{~m}$ (zie volgende paragraaf), een horizontale kettinglengte (afstand schip-net) van ca 4x waterdiepte $(20 \mathrm{~m})$ en de lengte van het vistuig van ongeveer $23 \mathrm{~m}$. Dimensies van vistuigen en informatie over de garnalenvismethoden zijn gebaseerd op beschrijvingen op www.vistikhetmaar.nl (https://vistikhetmaar.nl/lesmodules/vissersvaartuigen/; https://www.vistikhetmaar.nl/lesmodules/vissen-met-korren/garnalenkor/).

\subsubsection{Waterdiepte}

Waterdieptes op zeekaarten worden meestal in m diepte aangegeven als LAT (Lowest Astronomical Tide). Isolijnen en waterdiepten kunnen worden bekeken op de Maritieme Zeekaartviewer van Rijkswaterstaat (https://geoservices.rijkswaterstaat.nl/geoweb51/index.html?viewer=Maritime_Chart_Viewer.ENC). De kaart voor dit gebied is Zeekaart S57-RWS-ENC (ENC = Electronic Nautical Chart) (Figuur 4). De kaart toont waterdieptes van maximaal 3 tot $4 \mathrm{~m}$ LAT (dichtbij de dam), maar in de rest van het gebied is de diepte ongeveer 2 meter LAT. Aangezien bij alle getijden gevist mag worden, zijn getijvoorspellingen gedaan vanaf een locatie ten zuiden van de Brouwersdam (Brouwershavense Gat 8) (https://waterinfo.rws.nl/\#!/kaart/astronomische-getij/) (Figuur 5). Hoogwater is ongeveer $3 \mathrm{~m}$ boven LAT (Figuur 2). Daarmee bedragen de waterdiepten bij vloed ongeveer $2+3=5 \mathrm{~m}$. 


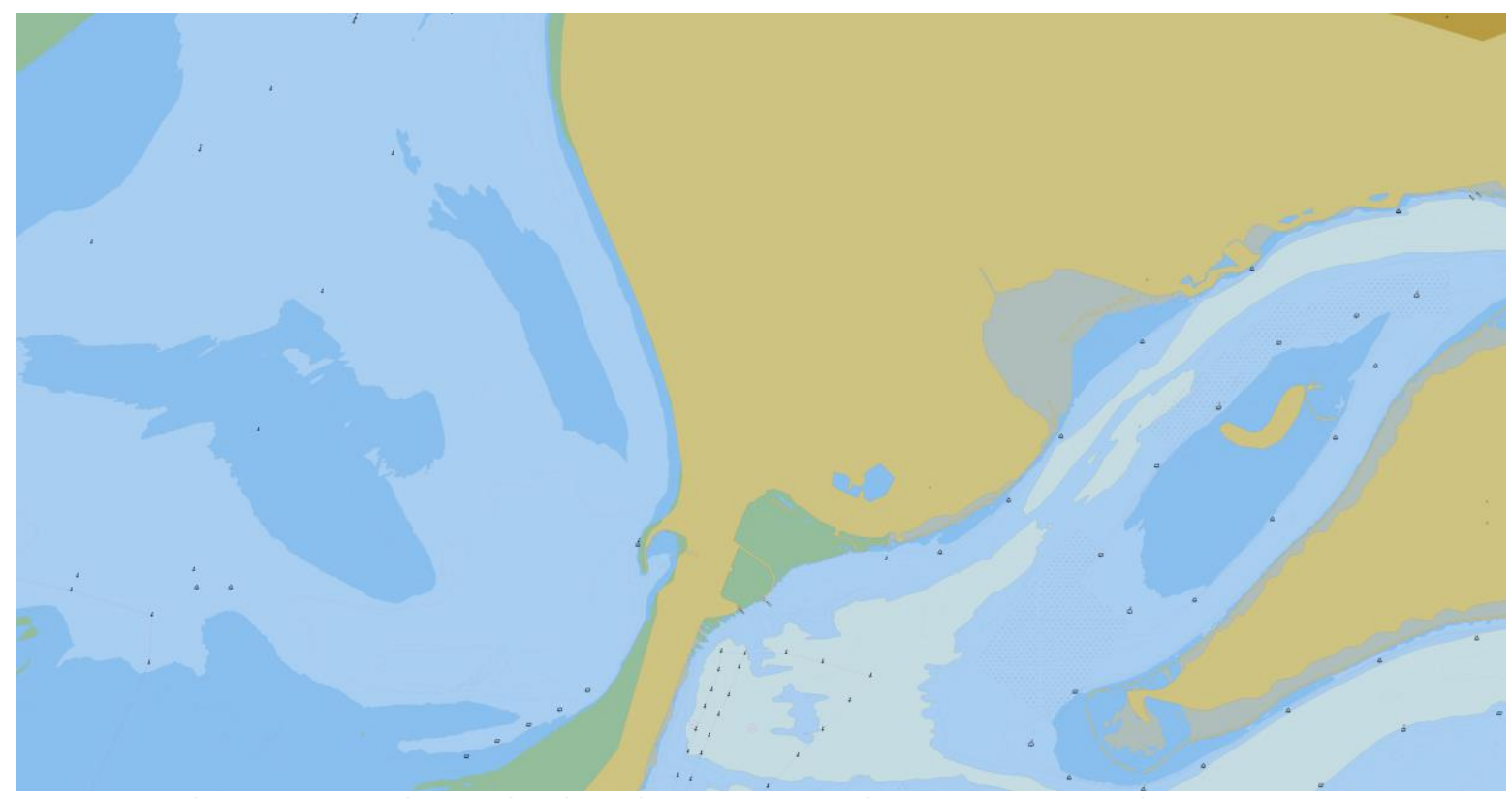

Figuur 4. Isolijnen en waterdieptes (LAT) op de Maritieme Zeekaart-viewer van Rijkswaterstaat (https://geoservices.rijkswaterstaat.nl/geoweb51/index.htm/?viewer=Maritime_Chart_Viewer.ENC). Lichtblauw: > 2 m diepte, donkerblauw: 1-2 m, groen 0-1 m.

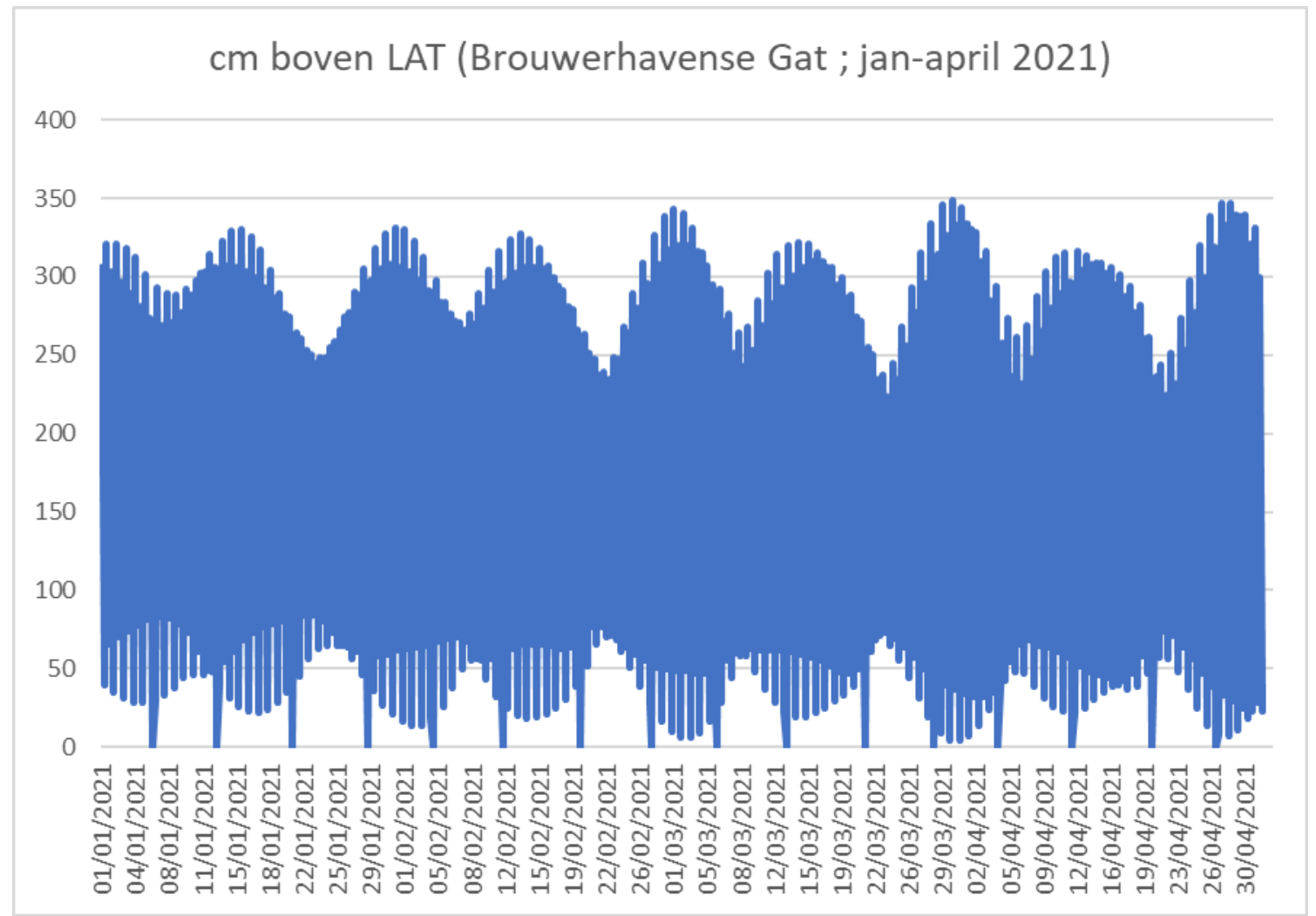

Figuur 5. Voorspelde waterstanden (cm LAT) bij Brouwerhavense Gat 08 (https://waterinfo.rws.nl/\#!/kaart/astronomische-getij/).

\subsubsection{Polygonen oesterbank}

Polygoondata van het oesterbank zijn afkomstig van Christianen et al. (2018) en zijn aangeleverd door Bureau Waardenburg. De polygonen (WGS84) zijn omgezet naar geprojecteerde data (WGS84 UTM31N). Er zijn drie bufferzones rondom het rif getekend: op 43 m (zwart), 50 m (blauw) en 100 m (groen). Omwille van het beheer zijn van deze polygonen met 66 hoekpunten handmatig ook vereenvoudigde versies gemaakt met 16 hoekpunten. 


\section{Resultaten}

\subsection{Effecten van visserij}

\subsubsection{Bodemberoerende visserij (TBB, DRB, OTB, HMD)}

Bodemberoerende visserijvormen zijn visserijvormen waarbij een actief vistuig wordt gebruikt dat door de bodem ploegt, over de bodem sleept, of schelpdieren uit de bodem opzuigt. Deze visserijvormen maken direct fysiek contact met de bodem en zullen daarom logischerwijs voor verstoring van de bodem zorgen. De verschillende visserijvormen en hun invloed op het bodemleven in de Voordelta zijn door Rijnsdorp et al. (2006) beschreven:

- $\quad$ Boomkor (TBB): "Dit vistuig, dat speciaal is ontwikkeld om de dieper gravende platvissoorten zoals tong te kunnen vangen, heeft een relatief groot effect op het benthos. Het vistuig rust op twee sloffen die door een metalen boom aan elkaar zijn verbonden en waartussen kettingen zijn gespannen die over de zeebodem slepen. De kettingen dringen hierbij in de zeebodem door. De penetratiediepte hangt af van de bodemsamenstelling, en is op grof zand geringer dan in fijner sediment. Experimenteel onderzoek heeft aangetoond dat de penetratiediepte tot $8 \mathrm{~cm}$ kan bedragen."

- Garnalenkor (DRB): "De garnalenkor is een lichte uitvoering van de boomkor. Het grootste verschil met de boomkor is het ontbreken van kettingen en een lichtere grondpees die is voorzien van rollers om zoveel mogelijk bodemmateriaal (grondvuil, krabben, schelpen, vis etc.) te laten liggen, maar wel de opspringende garnalen te vangen (klossenpees) en een kleinere maaswijdte tussen de 16 en $31 \mathrm{~mm} . "$

- $\quad$ Bodem-bordentrawl (OTB): "Dit grondnet wordt open gehouden door scheerborden die in de bodem doordringen. Om de vangstefficiëntie van het net te verhogen wordt de bordenspreiding vergroot door tussen de borden en de grondpees van het net een lange kabel te gebruiken (voorloper). Deze voorloper raakt alleen de oppervlakte van de zeebodem. Het contact met het benthos is beperkt tot de scheerborden, voorloper, grondpees en net."

- Ensis-visserij (HMD): Doordat het om een diep in de bodem levende mesheftsoort(en) (Ensis $s p$.) gaat zijn hierop toegespitste vistuigen ontworpen waarmee tot een diepte van $30 \mathrm{~cm}$ in de bodem het sediment wordt uitgezeefd. Vanwege de grote visdiepte in de bodem is de vissnelheid laag, tussen 0.1 en $0.2 \mathrm{mijl}$ (= ca $300 \mathrm{~m} / \mathrm{uur}$ ). Met behulp van water wordt het sediment vloeibaar gemaakt en wordt getracht zo veel mogelijk van het sediment door de spijlen van het vistuig te lozen. De maximaal toegestane visbreedte van het tuig is $1.25 \mathrm{~m} . "$

In het EU- project BENTHIS is een methode ontwikkeld om de voetafdruk $\left(\mathrm{km}^{2}\right.$ beroerde bodem per uur) te bepalen, gebaseerd op de dimensies van vistuigen (gewicht, breedte, etc.) en vissnelheid (Eigaard et al., 2016) (Figuur 2). Hoewel niet van direct belang voor het beantwoorden van de onderzoeksvraag geeft de methode wel inzicht in de verschillen in impact van de verschillende visserijmethoden. 

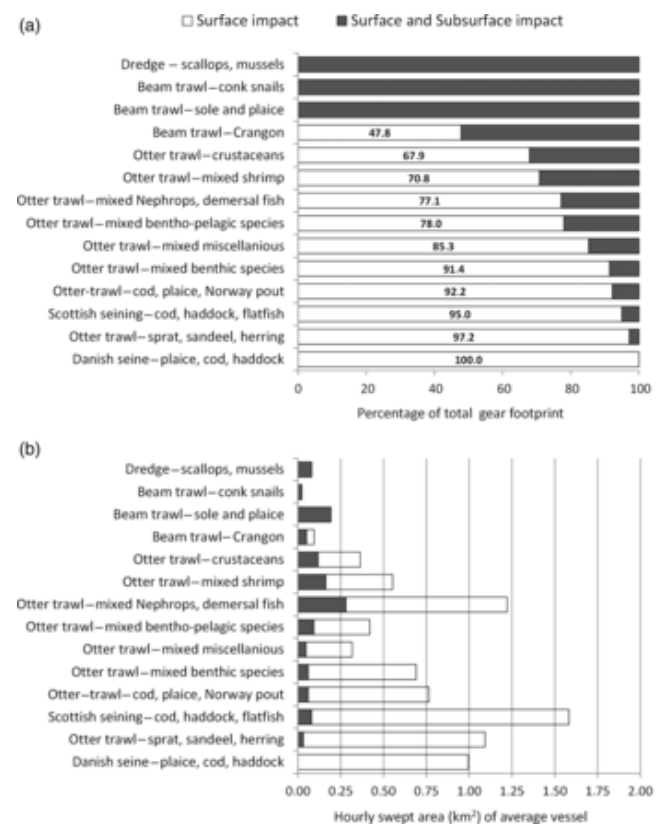

Figuur 6. Impact van verschillende bodemberoerende vistuigen (Eigaard et al., 2016). (a) percentage van het vistuig dat alleen de bodem raakt (wit) en dat door de bodem ploegt (zwart). (b) oppervlakte ( $\mathrm{km}^{2}$ per uur) die door het vistuig beroerd wordt.

\subsubsection{Visserij met vaste vistuigen}

Voor - eenmaal geplaatste - passieve vistuigen (vaste vistuigen) is de fysieke bodemverstoring waarschijnlijk klein. Passieve vistuigen zijn bijvoorbeeld manden, korven of staand want. Deze vistuigen staan op de bodem, en zullen de structuur van de bodem in mindere of meerdere mate fysiek beïnvloeden, afhankelijk van de dimensies van de netten. Verzwaarde onderdelen zoals ankers en lijnen die gebruikt worden om de vistuigen op hun plaats te houden kunnen lokaal invloed hebben. Ook kan een visnet over de bodem schuren door golven of stroming, waardoor lokale beschadiging van het bodemleven niet uitgesloten kan worden. Lijnen of ankers kunnen over de bodem schuren wanneer ze binnen worden gehaald, door het getij en golven heen en weer bewegen. Mogelijk zouden ze ook op drift kunnen raken.

In Rijnsdorp et al. (2006) wordt niet specifiek ingegaan op mogelijke effecten op het bodemleven. Wel wordt ervan uitgegaan dat de vaste vistuigen geen effect hebben op herstelopgaven voor benthossoorten (NB destijds was de aanwezigheid van platte oesters in het gebied nog niet bekend).

\section{Visserij met korven en fuiken (schietfuiken/kubben/korven) (FFK, FPO, FYK, HOK, HFK, KRK, SFK)}

Er zijn 21 standaardvergunninghouders (schietfuiken/kubben/korven en ankerkuil) bekend voor het visserijgebied Brouwerhavense Gat (Tabel 3).

Schietfuiken (SFK) zijn lage fuiken die meestal aan ankers op de bodem worden geplaatst. Kubben (SFK) zijn korte schietfuiken zonder vleugel (Rijnsdorp et al., 2006). Korven (FPO, KRK) bestaan uit een frame, omkleed met geknoopt netwerk of ander materiaal, al dan niet voorzien van aas en één of meerdere openingen voorzien van een inkeping. De korven kunnen aan elkaar gekoppeld worden tot korflijnen en met verzwaarde lijnen tot een stelsel van meerdere korven (Röckmann et al, 2015). Over effecten van deze vormen van visserij is verder geen literatuurinformatie gevonden tijdens deze quickscan. Het effect van deze vorm van visserij is daarom bepaald aan de hand van expert judgement (P. Molenaar, WMR). Korven worden in de praktijk aan elkaar geschakeld, een stuk of 30 achterelkaar met een aantal meter lijn ertussen $(>10 \mathrm{~m})$. Aan het begin en eind wordt een anker met een boei geplaatst. De lijn ligt op de bodem en kan door stroming of getij verplaatsen. Deze vorm van visserij heeft in principe een verwaarloosbare impact op het bodemleven, behalve uiteraard dat de doelsoorten (krabben, kreeften) worden weggevist. 


\section{Ankerkuilvisserij (ANK)}

Er zijn 21 standaardvergunning-houders (schietfuiken/kubben/korven en ankerkuil) bekend voor het visserijgebied Brouwerhavense Gat (zie ook paragraaf hierboven).

Een ankerkuil is een soort grote fuik die in stromend water met een anker wordt uitgezet, en voorzien is van een groot net (kuil) dat in een punt samenkomt. Waarschijnlijk beperkt de impact zich tot het effect van het anker op de bodem. Over deze vorm van visserij is verder geen informatie gevonden tijdens deze quickscan. Het effect van deze vorm van visserij is daarom ook bepaald aan de hand van expert judgement (P. Molenaar, WMR). Er is ingeschat dat het effect minimaal is, omdat alleen een anker op de bodem ligt. De rest van het net zweeft in het water.

\section{Staandwantvisserii (o.a. kieuwnetten of warnetten) (GNS, GNC, GTR, GN, GND)}

In het visserijgebied Brouwerhavense Gat zijn 2 vergunninghouders voor staand want (zie Tabel 3).

Een staand want (GNS; geankerd kieuwnet (staand net)) is een vistuig bestaande uit een lang verticaal net, dat omhoog gehouden wordt door een bovenpees met drijvers, en een verzwaarde onderpees dat aan de zeebodem wordt verankerd met ankers $(8-10 \mathrm{~kg})$. Deze netten zijn gewoonlijk ca $50 \mathrm{~m}$ lang per net-eenheid, en kunnen gekoppeld in lengte variëren van $200 \mathrm{~m}$ (kabeljauwvisserij bij wrakken) tot zelf $10 \mathrm{~km}$ (visserij op vlakte grond op tong). De uiteinden van het net worden gemarkeerd met een boei (Röckmann et al., 2015; Tamis et al., 2017). De Engelse naam is 'gillnet fisheries'.

De meeste staandwantstudies richten zich op bijvangst van vogels en zeezoogdieren (bv. Couperus et al., 2009, Rockmann et al., 2015). Ook zijn er diverse studies over effecten van verloren netten, die als spooknetten onder water door blijven vissen. Binnen Natura 2000 is er daarom veel aandacht voor effecten van staand want op bv. bruinvissen (Min LNV, 2020) en duikende zeevogels die erin verstrikt kunnen raken. Over de fysieke impact van staand want is veel minder bekend. Vergeleken met andere typen visserij, zoals de boomkorvisserij, lijkt de fysieke impact beperkt. Wel kan door cumulatie het effect lokaal groot zijn (veel netten, en/of frequent gebruik). Als een staand want is uitgezet, kunnen de drie componenten van het net kunnen bodemschade veroorzaken: de ankers, de verzwaarde bodemlijnen en het net zelf (. Als er sprake is van sterke stroming kan het net naar de bodem gedrukt worden en de bodem beroeren. Door stroming en getij kunnen de bodemlijn en het net heen en weer worden gesleept over de bodem en zo het bodemleven beschadigen. De grootste impact kan optreden wanneer het net wordt binnengehaald, vooral in structureel complexe habitats (in tegenstelling tot vlakke zandbodems).

In Denemarken werd in een experimentele staandwantstudie opgemeten wat de impact van de ankers was bij het binnenhalen van het net op twee steenriffen. Bij het ene steenrif (diepte 5-7 m) sleepte elk anker gemiddeld $117 \mathrm{~cm}$ over de bodem en bij het andere rif (diepte 4-5 m) gemiddeld $284 \mathrm{~cm}$ (Nordheim \& Wollny-Goerke, 2016, en referenties daarin, p83 en verder). In een andere experimentele studie, waarbij met stereo-camera's de bewegingen van het staand want net op een zandbodem zijn vastgelegd (Savina et al., 2017), bleek dat het net in de ordegrootte van $10 \mathrm{~cm}$ heen en weer bewoog over de bodem, met uitschieters tot 2 meter, in een gebied met weinig stroming (Savina et al. 2017). In een studie over mogelijkheden voor medegebruik in windparken geven Tamis et al. (2017) aan dat staand want door bodemberoering biogene rifgemeenschappen, zoals platteoesterbanken potentieel zouden kunnen verstoren.

Bovenstaande informatie laat zien dat staandwantvisserij oesterbanken potentieel negatief kan beïnvloeden, met name door het binnenhalen van de netten en het daarmee gepaard gaande slepen van ankers over de bodem, maar ook door de bewegingen van de verzwaarde bodemlijn over de bodem door stroming en getij.

\section{Ringzegen kleinschalige visserii (Gillnet Circling; GNC)}

Er zijn 2 vergunninghouders voor kleinschalige ringzegenvisserij (GNC) bekend in het visserijgebied Brouwerhavense Gat (zie Tabel 3). Deze vorm van visserij is geen echte zegenvisserij (zie verderop) en lijkt op staand want. Er wordt max. 1500 meter net gebruikt in de Oosterschelde, Westerschelde, 
Zeegat van Goeree en Brouwershavense Gat (pers. com LNV). Een van de twee zegenvisserijvergunninghouders vist bij de oesterbank.

LNV is bij deze visser op bezoek geweest. De doelsoorten van de ondernemer zijn harder en zeebaars. Hij gebruikt een visnet van ca 900 m lengte en zonder anker. De visser zegt soms een anker te gebruiken 'bij de stenen'. De onderpees (rood; Figuur 7) weegt 18 kg per $100 \mathrm{~m}$ en de visser geeft aan dat hij zijn net veelal binnenhaalt d.m.v. (een) sloep(en) naast het net, met een soort katrol (en dus niet, zoals bij een echte zegen, door het aantrekken van een cirkel tot een steeds kleinere cirkel vanaf het moederschip). Ook gaf hij aan dat hij wel eens platte oesters naar boven haalde die zich hadden "vastgebeten" aan het net (i.e. waren gesloten na aanraking door het net) (bron: LNV, E. Knegtering).

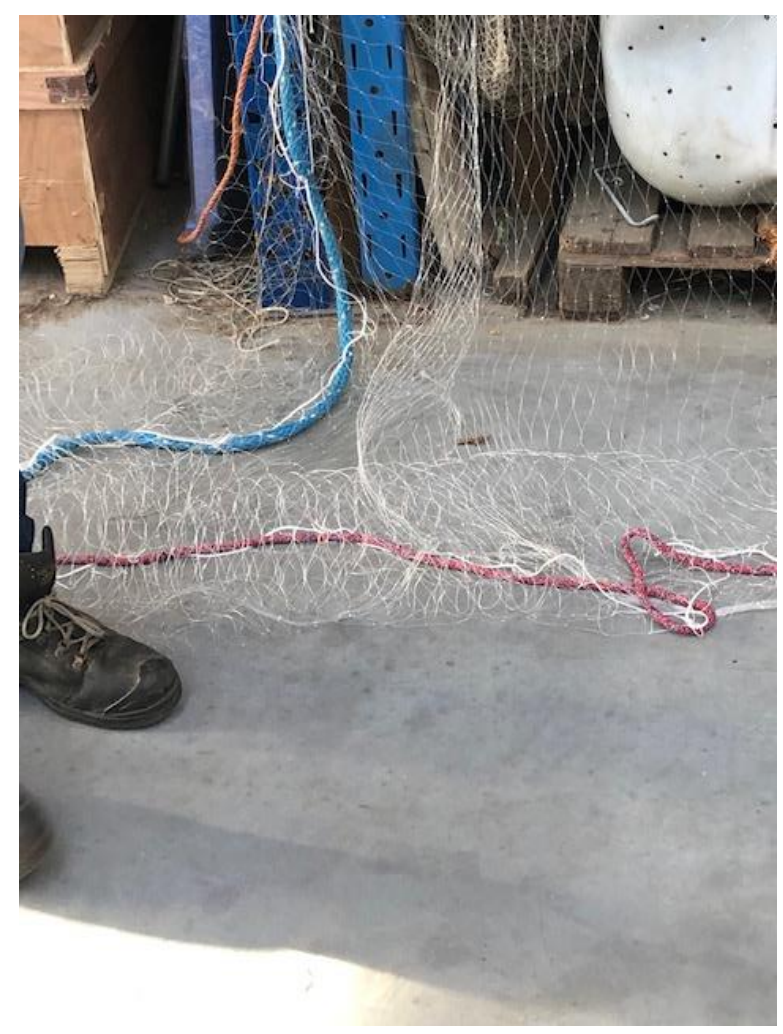

Figuur 7. GNC-net (foto: LNV, E. Knegtering).

Het gaat om een licht net, dat beperkte tijd wordt uitgezet (ca 15 minuten) en dat mogelijk over de oesters zal schuren wanneer het in het water staat, en bij het ophalen. De $18 \mathrm{~kg}$ van de onderpees weegt nog aanzienlijk minder in het water, daarnaast blijft er gezien het drijfvermogen van het netwerk en de bovenpees weinig gewicht over dat over de bodem kan slepen. Er zal geen groot oppervlak worden beroerd, omdat het net niet in een cirkel wordt dichtgetrokken. Uitgaande van de $10 \mathrm{~cm}$ heen en weer beweging zoals in de hierboven beschreven Deense studie, en een netlengte van $900 \mathrm{~m}$, zal een oppervlakte van ca $0.10 \mathrm{~m} \times 900 \mathrm{~m}=90 \mathrm{~m} 2$ per keer mogelijk worden verstoord. Waarschijnlijk is de verstoring licht van aard, omdat er verder geen ankers worden gebruikt. Op basis van expert judgement (P. Molenaar, WMR) is ingeschat dat dit standwanttuig een verwaarloosbare bodemberoering zal hebben. Verder heeft het staand want zelf op een oesterbank waarschijnlijk een verwaarloosbaar effect, dat beperkt blijft tot het mogelijk omkeren van een aantal oesters.

\section{Hengelvisserii (LHP)}

Hengelvisserij is gericht op zeebaars en kabeljauw. Er worden geen effecten verwacht op het oesterbank, anders dan eventueel verliezen van vislood.

\subsubsection{Mosselzaadinvanginstallaties (MZI's)}

De komende jaren (2021-2026) is in het visserijgebied Brouwerhavense Gat een MZI-gebied aan de zuidkant van de Brouwersdam voorzien (Min LNV, 2020), maar niet aan de noordkant waar de oesterbank ligt. 
Er bestaan verschillende typen mosselzaadinvanginstallaties (MZI's) bestaande uit drijvende of aan de bodem verankerde constructies met touwen waar zich jonge mosseltjes ('mosselzaad') op kunnen vestigen (Kamermans \& Smaal, 2008; Kamermans et al., 2014; Kamermans \& Smaal, 2014). De MZIinstallatie zelf kan invloed hebben op de oesterbank, doordat ankers en touwen van de installatie over de bodem kunnen schuren. Ook is er kans op depositie van afvalstoffen van de mosselen op de bodem, hoewel daarvoor in de onderzochte MZI's op zandige bodems geen aanwijzingen zijn gevonden (Kamermans et al., 2014; Kamermans \& Smaal, 2014). Het effect op oesterbanken is niet onderzocht, omdat de MZI's daar niet waren gesitueerd. De installaties zijn verder vrij groot in omvang en blijven een deel van het jaar of jaarrond op een vaste locatie liggen. Indien een MZI op de oesterbank zou worden geplaatst kan er fysiek gezien mogelijk geen onderzoek worden uitgevoerd naar oesters, omdat de MZI-constructie dan in de weg staat. In de praktijk zal er geen MZI op de oesterbank worden geplaatst, omdat het er te ondiep is.

\subsection{Begrenzing}

De minimale bufferzone voor garnalenvisserij als voorbeeld van bodemberoerende visserij wordt ( $4 *$ $5 m)+23 m=43 m$ (zie Figuur 3). Ten bate van het beheer zijn ook ruimere bufferzones van $50 \mathrm{~m}$ en van $100 \mathrm{~m}$ uitgewerkt.

De oesterbank (paars; Christianen et al., 2018) met de drie bufferzones (43, 50 and $100 \mathrm{~m}$ ) worden weergegeven in Figuur 8 en Tabel 5 toont de coördinaten van de punten waardoor de begrenzingslijnen lopen. Een vereenvoudigde vorm is weergegeven in Figuur 9 en begrenzingscoördinaten in Tabel 7.

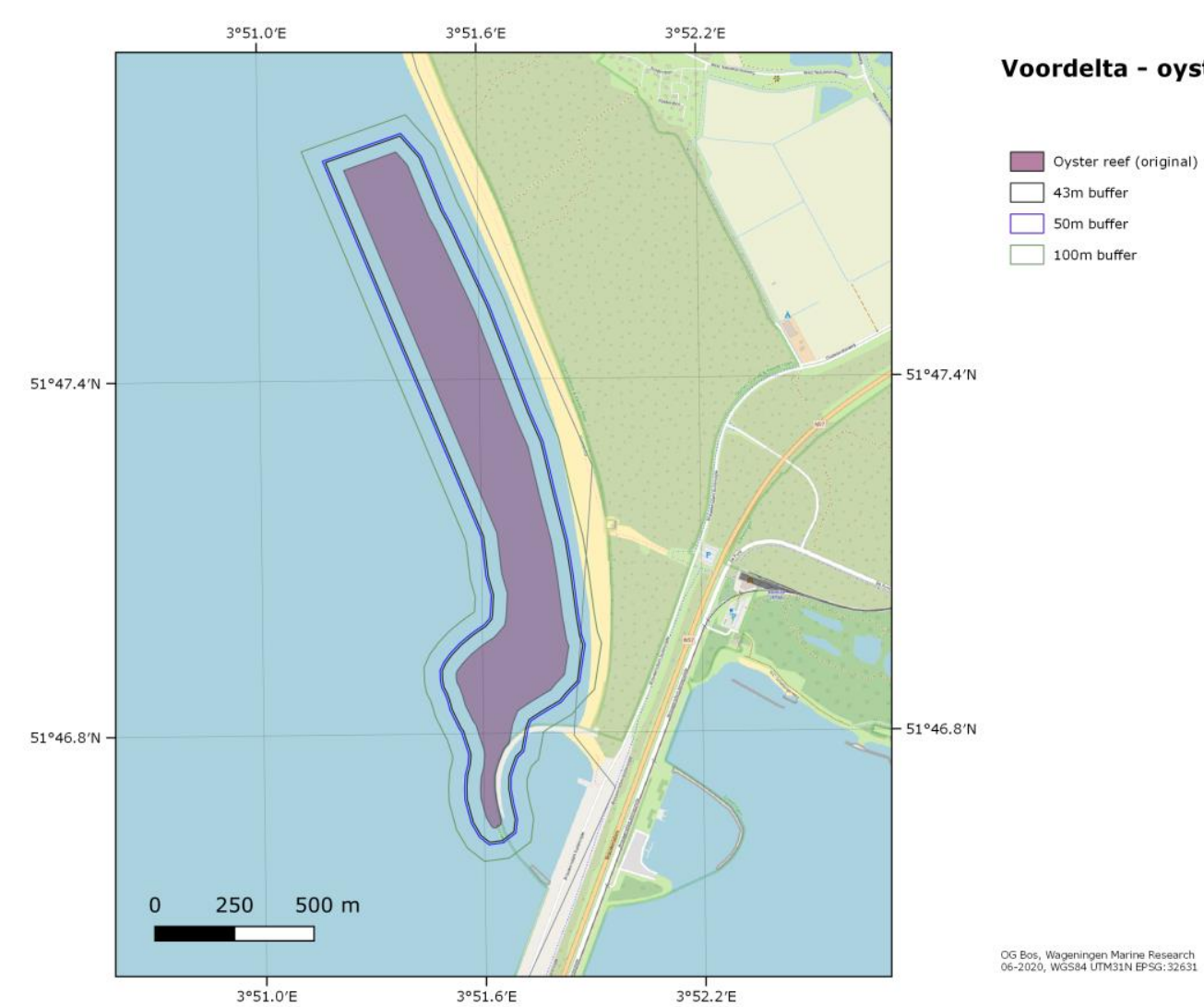

Figuur 8. Oesterbank in de Voordelta (paars) (Christianen et al., 2018), met de 43 m, $50 \mathrm{~m}$ en $100 \mathrm{~m}$ bufferzones. 


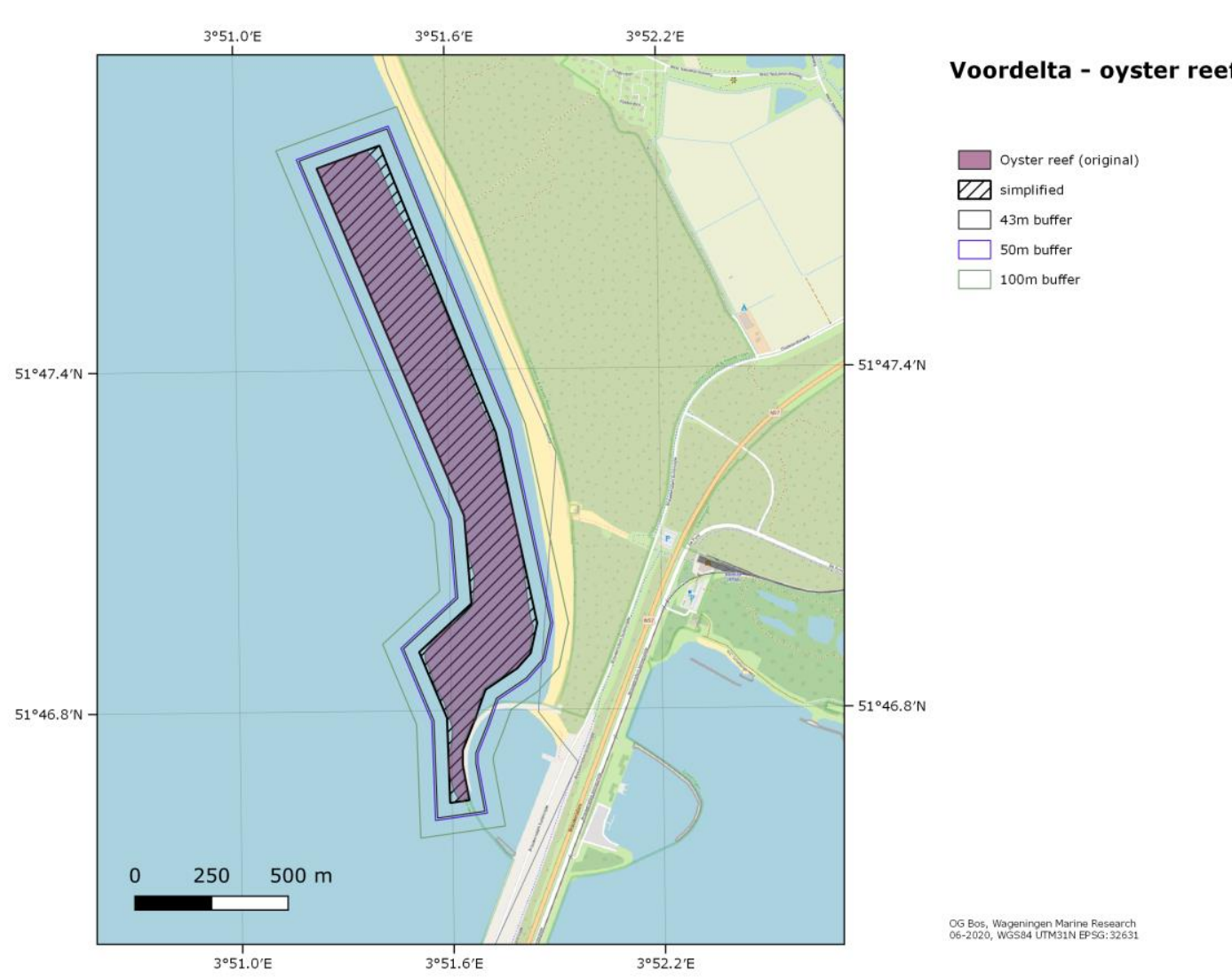

Figuur 9. Versimpelde begrenzing van de oesterbank in de Voordelta (paars) (Christianen et al., 2018), met vereenvoudigde de $43 \mathrm{~m}, 50 \mathrm{~m}$ en $100 \mathrm{~m}$ bufferzones. 
Tabel 5. Coördinaten (WGS84) van de begrenzingen van het oesterbank (Christianen et al., 2018), met de $43 \mathrm{~m}, 50 \mathrm{~m}$ en $100 \mathrm{~m}$ bufferzones.

\begin{tabular}{|c|c|c|c|c|c|c|c|c|}
\hline 읍 & 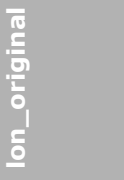 & 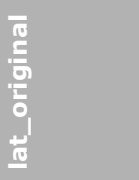 & 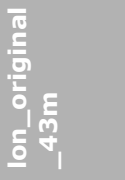 & $\begin{array}{l}\frac{1}{10} \\
\frac{5}{5} \\
\frac{7}{6} \\
\frac{1}{10} \\
\frac{9}{9}\end{array}$ & 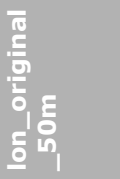 & 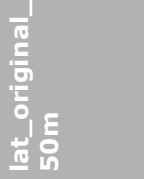 & 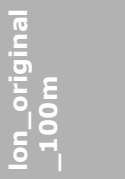 & 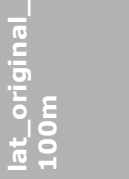 \\
\hline 1 & 3.85392 & 51.79594 & 3.85309 & 51.79617 & 3.85296 & 51.79621 & 3.85200 & 51.79648 \\
\hline 2 & 3.85631 & 51.79644 & 3.85650 & 51.79689 & 3.85653 & 51.79697 & 3.85676 & 51.79749 \\
\hline 3 & 3.85683 & 51.79607 & 3.85737 & 51.79627 & 3.85746 & 51.79631 & 3.85808 & 51.79655 \\
\hline 4 & 3.85778 & 51.79460 & 3.85834 & 51.79476 & 3.85844 & 51.79479 & 3.85909 & 51.79498 \\
\hline 5 & 3.85812 & 51.79421 & 3.85868 & 51.79438 & 3.85877 & 51.79441 & 3.85942 & 51.79461 \\
\hline 6 & 3.85980 & 51.79192 & 3.86037 & 51.79207 & 3.86047 & 51.79209 & 3.86114 & 51.79226 \\
\hline 7 & 3.86068 & 51.79046 & 3.86126 & 51.79059 & 3.86136 & 51.79062 & 3.86204 & 51.79077 \\
\hline 8 & 3.86160 & 51.78892 & 3.86218 & 51.78906 & 3.86227 & 51.78908 & 3.86294 & 51.78925 \\
\hline 9 & 3.86217 & 51.78809 & 3.86276 & 51.78820 & 3.86286 & 51.78822 & 3.86355 & 51.78836 \\
\hline 10 & 3.86268 & 51.78668 & 3.86328 & 51.78677 & 3.86338 & 51.78678 & 3.86409 & 51.78689 \\
\hline 11 & 3.86320 & 51.78535 & 3.86381 & 51.78542 & 3.86391 & 51.78544 & 3.86463 & 51.78552 \\
\hline 12 & 3.86343 & 51.78444 & 3.86404 & 51.78449 & 3.86414 & 51.78450 & 3.86486 & 51.78456 \\
\hline 13 & 3.86365 & 51.78328 & 3.86427 & 51.78333 & 3.86437 & 51.78334 & 3.86509 & 51.78340 \\
\hline 14 & 3.86382 & 51.78263 & 3.86442 & 51.78272 & 3.86452 & 51.78274 & 3.86523 & 51.78285 \\
\hline 15 & 3.86392 & 51.78244 & 3.86456 & 51.78247 & 3.86467 & 51.78248 & 3.86541 & 51.78252 \\
\hline 16 & 3.86371 & 51.78164 & 3.86429 & 51.78145 & 3.86439 & 51.78142 & 3.86507 & 51.78121 \\
\hline 17 & 3.86332 & 51.78139 & 3.86378 & 51.78113 & 3.86385 & 51.78109 & 3.86439 & 51.78079 \\
\hline 18 & 3.86307 & 51.78121 & 3.86348 & 51.78091 & 3.86355 & 51.78086 & 3.86402 & 51.78051 \\
\hline 19 & 3.86269 & 51.78107 & 3.86301 & 51.78074 & 3.86306 & 51.78068 & 3.86342 & 51.78029 \\
\hline 20 & 3.86222 & 51.78090 & 3.86254 & 51.78057 & 3.86260 & 51.78051 & 3.86298 & 51.78013 \\
\hline 21 & 3.86166 & 51.78067 & 3.86207 & 51.78038 & 3.86215 & 51.78033 & 3.86274 & 51.78003 \\
\hline 22 & 3.86155 & 51.78061 & 3.86193 & 51.78017 & 3.86203 & 51.78015 & 3.86273 & 51.78002 \\
\hline 23 & 3.86133 & 51.78028 & 3.86173 & 51.77951 & 3.86182 & 51.77948 & 3.86249 & 51.77926 \\
\hline 24 & 3.86115 & 51.77971 & 3.86145 & 51.77935 & 3.86154 & 51.77931 & 3.86216 & 51.77906 \\
\hline 25 & 3.86092 & 51.77956 & 3.86126 & 51.77905 & 3.86136 & 51.77903 & 3.86204 & 51.77888 \\
\hline 26 & 3.86068 & 51.77918 & 3.86113 & 51.77878 & 3.86123 & 51.77877 & 3.86195 & 51.77869 \\
\hline 27 & 3.86050 & 51.77884 & 3.86112 & 51.77842 & 3.86122 & 51.77843 & 3.86194 & 51.77846 \\
\hline 28 & 3.86049 & 51.77840 & 3.86123 & 51.77799 & 3.86133 & 51.77800 & 3.86204 & 51.77809 \\
\hline 29 & 3.86062 & 51.77792 & 3.86139 & 51.77756 & 3.86150 & 51.77757 & 3.86223 & 51.77759 \\
\hline 30 & 3.86076 & 51.77754 & 3.86132 & 51.77722 & 3.86141 & 51.77718 & 3.86209 & 51.77694 \\
\hline 31 & 3.86074 & 51.77743 & 3.86101 & 51.77707 & 3.86107 & 51.77702 & 3.86151 & 51.77666 \\
\hline 32 & 3.86064 & 51.77738 & 3.86078 & 51.77697 & 3.86082 & 51.77691 & 3.86110 & 51.77648 \\
\hline 33 & 3.86054 & 51.77734 & 3.86022 & 51.77693 & 3.86019 & 51.77686 & 3.85997 & 51.77639 \\
\hline 34 & 3.86040 & 51.77733 & 3.85983 & 51.77712 & 3.85976 & 51.77707 & 3.85920 & 51.77678 \\
\hline 35 & 3.86032 & 51.77737 & 3.85948 & 51.77749 & 3.85939 & 51.77747 & 3.85871 & 51.77730 \\
\hline 36 & 3.86007 & 51.77764 & 3.85922 & 51.77813 & 3.85911 & 51.77812 & 3.85839 & 51.77806 \\
\hline 37 & 3.85984 & 51.77819 & 3.85920 & 51.77847 & 3.85910 & 51.77847 & 3.85838 & 51.77848 \\
\hline 38 & 3.85983 & 51.77846 & 3.85924 & 51.77882 & 3.85914 & 51.77883 & 3.85842 & 51.77890 \\
\hline 39 & 3.85986 & 51.77875 & 3.85938 & 51.77914 & 3.85927 & 51.77915 & 3.85856 & 51.77923 \\
\hline 40 & 3.85999 & 51.77907 & 3.85939 & 51.77925 & 3.85929 & 51.77925 & 3.85857 & 51.77929 \\
\hline 41 & 3.86001 & 51.77921 & 3.85941 & 51.77938 & 3.85931 & 51.77938 & 3.85858 & 51.77936 \\
\hline 42 & 3.86004 & 51.77938 & 3.85940 & 51.77945 & 3.85930 & 51.77944 & 3.85838 & 51.77976 \\
\hline 43 & 3.86002 & 51.77952 & 3.85917 & 51.77991 & 3.85907 & 51.77989 & 3.85833 & 51.77984 \\
\hline 44 & 3.85976 & 51.78002 & 3.85909 & 51.78007 & 3.85899 & 51.78004 & 3.85827 & 51.77990 \\
\hline 45 & 3.85965 & 51.78024 & 3.85899 & 51.78016 & 3.85890 & 51.78013 & 3.85780 & 51.78051 \\
\hline 46 & 3.85952 & 51.78036 & 3.85858 & 51.78068 & 3.85849 & 51.78066 & 3.85769 & 51.78078 \\
\hline 47 & 3.85917 & 51.78082 & 3.85848 & 51.78093 & 3.85838 & 51.78091 & 3.85760 & 51.78093 \\
\hline 48 & 3.85908 & 51.78104 & 3.85837 & 51.78113 & 3.85827 & 51.78111 & 3.85742 & 51.78117 \\
\hline 49 & 3.85894 & 51.78128 & 3.85821 & 51.78133 & 3.85811 & 51.78131 & 3.85736 & 51.78138 \\
\hline 50 & 3.85881 & 51.78145 & 3.85817 & 51.78147 & 3.85807 & 51.78146 & 3.85733 & 51.78149 \\
\hline 51 & 3.85879 & 51.78153 & 3.85816 & 51.78153 & 3.85806 & 51.78153 & 3.85732 & 51.78189 \\
\hline 52 & 3.85878 & 51.78157 & 3.85815 & 51.78178 & 3.85805 & 51.78180 & 3.85760 & 51.78226 \\
\hline 53 & 3.85877 & 51.78170 & 3.85831 & 51.78199 & 3.85822 & 51.78202 & 3.85796 & 51.78256 \\
\hline 54 & 3.85884 & 51.78179 & 3.85859 & 51.78223 & 3.85852 & 51.78227 & 3.85848 & 51.78289 \\
\hline 55 & 3.85907 & 51.78198 & 3.85904 & 51.78251 & 3.85897 & 51.78256 & 3.85901 & 51.78316 \\
\hline 56 & 3.85946 & 51.78223 & 3.85952 & 51.78276 & 3.85945 & 51.78281 & 3.85938 & 51.78333 \\
\hline 57 & 3.85989 & 51.78245 & 3.85984 & 51.78290 & 3.85979 & 51.78295 & 3.85959 & 51.78341 \\
\hline 58 & 3.86019 & 51.78258 & 3.86013 & 51.78301 & 3.86006 & 51.78306 & 3.85965 & 51.78345 \\
\hline 59 & 3.86053 & 51.78271 & 3.86031 & 51.78313 & 3.86023 & 51.78318 & 3.85969 & 51.78386 \\
\hline 60 & 3.86077 & 51.78288 & 3.86043 & 51.78322 & 3.86033 & 51.78325 & 3.85947 & 51.78435 \\
\hline 61 & 3.86102 & 51.78305 & 3.86046 & 51.78335 & 3.86036 & 51.78336 & 3.85929 & 51.78543 \\
\hline 62 & 3.86108 & 51.78330 & 3.86052 & 51.78391 & 3.86042 & 51.78390 & 3.85526 & 51.79152 \\
\hline 63 & 3.86115 & 51.78395 & 3.86029 & 51.78445 & 3.86019 & 51.78443 & 3.85200 & 51.79648 \\
\hline 64 & 3.86090 & 51.78452 & 3.86010 & 51.78556 & 3.86000 & 51.78554 & & \\
\hline 65 & 3.86071 & 51.78566 & 3.85603 & 51.79171 & 3.85594 & 51.79169 & & \\
\hline 66 & 3.85661 & 51.79186 & 3.85309 & 51.79617 & 3.85296 & 51.79621 & & \\
\hline 67 & 3.85392 & 51.79594 & & & & & & \\
\hline
\end{tabular}

Tabel 6. Coördinaten (WGS84) van de vereenvoudigde begrenzingen van het oesterbank (Christianen et al., 2018), met de $43 \mathrm{~m}, 50 \mathrm{~m}$ en $100 \mathrm{~m}$ bufferzones. 


\begin{tabular}{|c|c|c|c|c|c|c|c|c|}
\hline 읍 & 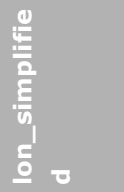 & 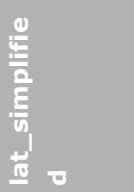 & 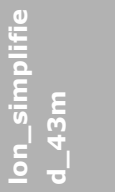 & ह & 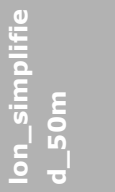 & 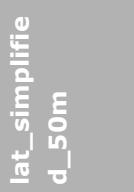 & 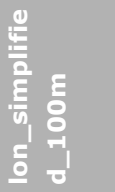 & 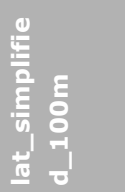 \\
\hline 1 & 3.85392 & 51.79594 & 3.8531 & 51.79616 & 3.85296 & 51.79620 & 3.85200 & 51.79647 \\
\hline 2 & 3.85691 & 51.79659 & 3.85727 & 51.79708 & 3.85733 & 51.79716 & 3.85775 & 51.79773 \\
\hline 3 & 3.86225 & 51.78813 & 3.86285 & 51.78824 & 3.86295 & 51.78826 & 3.86365 & 51.78839 \\
\hline 4 & 3.86410 & 51.78254 & 3.86474 & 51.78253 & 3.86484 & 51.78253 & 3.86558 & 51.78253 \\
\hline 5 & 3.86378 & 51.78166 & 3.86435 & 51.78147 & 3.86445 & 51.78144 & 3.86511 & 51.78123 \\
\hline 6 & 3.86314 & 51.78121 & 3.86355 & 51.78092 & 3.86361 & 51.78087 & 3.86409 & 51.78053 \\
\hline 7 & 3.86162 & 51.78059 & 3.86213 & 51.78034 & 3.86222 & 51.78030 & 3.86282 & 51.78001 \\
\hline 8 & 3.86112 & 51.77974 & 3.86170 & 51.77960 & 3.86179 & 51.77958 & 3.86247 & 51.77942 \\
\hline 9 & 3.86051 & 51.77882 & 3.86113 & 51.77875 & 3.86123 & 51.77873 & 3.86196 & 51.77864 \\
\hline 10 & 3.86050 & 51.77840 & 3.86113 & 51.77843 & 3.86123 & 51.77844 & 3.86195 & 51.77847 \\
\hline 11 & 3.86080 & 51.77736 & 3.86152 & 51.77703 & 3.86164 & 51.77698 & 3.86249 & 51.77659 \\
\hline 12 & 3.85989 & 51.77729 & 3.85928 & 51.77685 & 3.85918 & 51.77678 & 3.85848 & 51.77627 \\
\hline 13 & 3.85979 & 51.77978 & 3.85917 & 51.77970 & 3.85906 & 51.77969 & 3.85834 & 51.77959 \\
\hline 14 & 3.85851 & 51.78172 & 3.85776 & 51.78182 & 3.85764 & 51.78184 & 3.85678 & 51.78196 \\
\hline 15 & 3.86100 & 51.78313 & 3.86036 & 51.78329 & 3.86025 & 51.78332 & 3.85951 & 51.78350 \\
\hline 16 & 3.86071 & 51.78570 & 3.86009 & 51.78561 & 3.85999 & 51.78560 & 3.85928 & 51.78550 \\
\hline 17 & 3.85392 & 51.79594 & 3.85310 & 51.79616 & 3.85296 & 51.79620 & 3.85200 & 51.79647 \\
\hline
\end{tabular}




\section{$4 \quad$ Conclusies en aanbevelingen}

\subsection{Effecten van visserij}

De beoordeling van de effecten van de verschillende visserijvormen op de oesterbank (met een focus op benthos/ hardsubstraatbewonende organismen) is weergegeven in Tabel 7.

Verstorend: Alle vormen van bodemberoerende visserij (sleepnetvisserij, garnalenvisserij, bordenvisserij en schelpdiervisserij) zijn niet verenigbaar met bescherming en ongestoord onderzoek naar de ontwikkeling van de oesterbank en geassocieerde biodiversiteit in de Voordelta. Deze visserijvormen verstoren allemaal in meer of mindere mate de bodem en zijn dus schadelijk voor de integriteit van de oesterbank. MZI's zijn mogelijk niet verenigbaar met het onderzoek door hun ruimtebeslag. Er zijn echter geen MZI's gepland bij de oesterbank in de periode 2021-2026. In de praktijk is er geen probleem, want deze vormen van visserij vinden nu niet plaats in bij de oesterbank. Deze vormen van visserij dienen ter bescherming van de oesterbank in het gebied te worden uitgesloten.

Weinig verstorend: Mogelijk wel verenigbaar met het onderzoek zijn de verschillende vormen van visserij met vaste vistuigen, zoals visserij met korven en fuiken, ankerkuilvisserij, en bepaalde vormen van staande netten. Omdat effecten niet uit te sluiten zijn, zou getoetst moeten worden of de visserij verstorend is als deze zou worden toegelaten. In de praktijk vormen deze vormen van visserij geen probleem, want ze komen niet voor bij de oesterbank. Uit voorzorg zouden deze vormen van visserij ter bescherming van het oesterbank kunnen worden uitgesloten, tenzij kan worden aangetoond dat ze geen schade veroorzaken.

\section{Weinig/niet verstorend:}

De enige gebruikte vorm is het GNC-tuig (kieuwnet (omringend); gillnets (circling)) voor visserij op zeebaars en harders, die de oesterbank waarschijnlijk niet aantast. Omdat de verwachte impact op de oesterbank laag is zou de visserij gehandhaafd kunnen blijven als kan worden bevestigd dat ze geen schade veroorzaakt.

Tabel 7. Beoordeling effecten van de toegestane visserij in het bodembeschermingsgebied Voordelta op de integriteit van de oesterbank.

\begin{tabular}{|c|c|c|c|c|c|c|c|c|}
\hline Type & vistuigen & code & 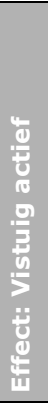 & 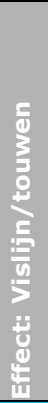 & 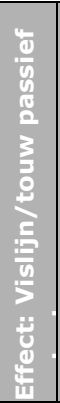 & 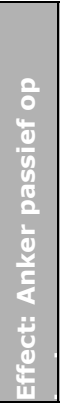 & $\begin{array}{l}\text { Beoordeling } \\
\text { Bodemberoeri } \\
\text { ng }\end{array}$ & Reden \\
\hline \multicolumn{9}{|l|}{$\begin{array}{l}\text { A. } \\
\text { Sleepnetvisserij }\end{array}$} \\
\hline $\begin{array}{l}\text { sleepnetvisserij } \\
<260 \mathrm{pk}(191 \\
\mathrm{kW}) \text { incl } \\
\text { garnalenvisserij } \\
\text { met boomkor }\end{array}$ & $\begin{array}{l}\text { boomkor, } \\
\text { demersale borden } \\
\text { en/of een } \\
\text { pelagische borden }\end{array}$ & $\begin{array}{l}\text { TBB, } \\
\text { OTB, } \\
\text { OTT, } \\
\text { PTB, } \\
\text { SDN, } \\
\text { SPR of } \\
\text { SSC, } \\
\text { OTM of } \\
\text { PTM }\end{array}$ & $x$ & & & & Verstorend & $\begin{array}{l}\text { Vistuig sleept } \\
\text { door bodem } \\
\text { (behalve bij } \\
\text { midwater trawls) }\end{array}$ \\
\hline garnalenkor & garnalenkor & DRB & $x$ & & & & Verstorend & $\begin{array}{l}\text { Kor sleept } \\
\text { over/door } \\
\text { bodem }\end{array}$ \\
\hline
\end{tabular}




\begin{tabular}{|c|c|c|c|c|c|c|c|c|}
\hline Type & vistuigen & code & 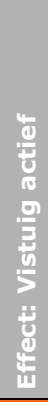 & 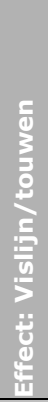 & 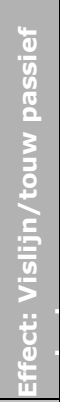 & 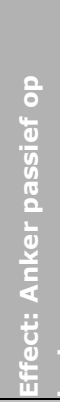 & $\begin{array}{l}\text { Beoordeling } \\
\text { Bodemberoeri } \\
\text { ng }\end{array}$ & Reden \\
\hline $\begin{array}{l}\text { bordenvisserij } \\
\text { (anders dan op } \\
\text { garnalen); }\end{array}$ & borden & OTB & $x$ & & & & Verstorend & $\begin{array}{l}\text { Borden slepen } \\
\text { over bodem }\end{array}$ \\
\hline $\begin{array}{l}\text { schelpdiervisseri } \\
\mathrm{j} \text { (met inbegrip } \\
\text { van } \\
\text { Ensis-visserij en } \\
\text { uitgezonderd } \\
\text { Spisula- } \\
\text { visserij); }\end{array}$ & $\begin{array}{l}\text { kor/gemechaniseer } \\
\text { de dreg, eventueel } \\
\text { met zuiger }\end{array}$ & $\begin{array}{l}\text { DRB, } \\
\text { HMD }\end{array}$ & $\mathrm{x}$ & & & & Verstorend & $\begin{array}{l}\text { Bodem wordt } \\
\text { opgezogen/gedre } \\
\text { gd }\end{array}$ \\
\hline \multicolumn{9}{|l|}{$\begin{array}{l}\text { B. Visserij } \\
\text { met vaste } \\
\text { vistuigen }\end{array}$} \\
\hline $\begin{array}{l}\text { visserij met } \\
\text { korven en } \\
\text { fuiken }\end{array}$ & $\begin{array}{l}\text { schietfuiken/ } \\
\text { kubben/ korven }\end{array}$ & $\begin{array}{l}\text { FFK, } \\
\text { FPO, } \\
\text { FYK, } \\
\text { HOK, } \\
\text { HFK, } \\
\text { KRK, } \\
\text { SFK }\end{array}$ & & & $x$ & $x$ & $\begin{array}{l}\text { Weinig } \\
\text { verstorend }\end{array}$ & $\begin{array}{l}\text { Mogelijk klein } \\
\text { effect van } \\
\text { anker/touwen op } \\
\text { bodem. Maar } \\
\text { deel van } \\
\text { benthische } \\
\text { biodiversiteit } \\
\text { (krabben/kreefte } \\
\text { n) wordt } \\
\text { onttrokken }\end{array}$ \\
\hline Ankerkuilvisserij & ankerkuil & ANK & & & & $x$ & $\begin{array}{l}\text { Weinig } \\
\text { /niet } \\
\text { verstorend }\end{array}$ & $\begin{array}{l}\text { Mogelijk effect } \\
\text { van anker op } \\
\text { bodem. Net in } \\
\text { waterkolom. }\end{array}$ \\
\hline $\begin{array}{l}\text { Staandwant- } \\
\text { visserij }\end{array}$ & $\begin{array}{l}\text { kieuwnetten of } \\
\text { warnetten }\end{array}$ & $\begin{array}{l}\text { GNS, } \\
\text { GTR, } \\
\text { GN, } \\
\text { GND }\end{array}$ & & & $x$ & $x$ & $\begin{array}{l}\text { Weinig } \\
\text { verstorend }\end{array}$ & $\begin{array}{l}\text { Klein effect van } \\
\text { ankers/touwen } \\
\text { op bodem }\end{array}$ \\
\hline $\begin{array}{l}\text { Ringzegen } \\
\text { kleinschalige } \\
\text { visserij }\end{array}$ & $\begin{array}{l}\text { kieuwnet } \\
\text { (omringend) / } \\
\text { ringzegen } \\
\text { kleinschalige } \\
\text { visserij }\end{array}$ & GNC & & & $x$ & & $\begin{array}{l}\text { Weinig /geen } \\
\text { verstoring }\end{array}$ & $\begin{array}{l}\text { Net staat op } \\
\text { bodem, wordt } \\
\text { niet over bodem } \\
\text { getrokken. }\end{array}$ \\
\hline hengelvisserij & & LHP & & & $x$ & & $\begin{array}{l}\text { Geen } \\
\text { verstoring }\end{array}$ & $\begin{array}{l}\text { Geen verstoring } \\
\text { bodem }\end{array}$ \\
\hline \multicolumn{9}{|l|}{$\begin{array}{l}\text { C. Overige } \\
\text { visserij }\end{array}$} \\
\hline $\begin{array}{l}\text { Mosselzaadinvan } \\
\text { g-installaties }\end{array}$ & $\begin{array}{l}\text { Mosselzaadinvang- } \\
\text { installaties (MZI) }\end{array}$ & & & & $x$ & $x$ & Verstorend & $\begin{array}{l}\text { Touwen en } \\
\text { ankers schuren } \\
\text { mogelijk over } \\
\text { bodem. } \\
\text { Ruimtebeslag is } \\
\text { een probleem. }\end{array}$ \\
\hline
\end{tabular}

\subsubsection{Aanbevelingen}

Om inzicht te krijgen in het bodemcontact van het GNC net adviseren we een kleine proef uit te voeren met camera's (zie 3.1.2).

Om de bodemimpact van kleinere visserijvormen systematischer te beoordelen, zoals dat ook in ICES of OSPAR-verband gebruikelijk is ${ }^{1}$, zijn de volgende gegevens nodig:

\footnotetext{
${ }^{1}$ bv https://oap.ospar.org/en/ospar-assessments/intermediate-assessment-2017/key-messages-and-highlights/benthic-habitatsaffected-by-bottom-fisheries/, of Rijnsdorp et al. (2016)
} 
- Informatie over de fysieke impact van de visserijvormen op de bodem op basis van de dimensies van het vistuig (gewicht, breedte, etc.), de vissnelheid of visduur, en gedrag van het vistuig (zie Eigaard et al. 2016).

- Gegevens over de kwetsbaarheid van de habitat of doelsoorten voor verstoring

- Gegevens over de visserij-inspanning (visuren per locatie).

\subsection{Begrenzing}

Er zijn drie bufferzones voorgesteld om het oesterbank in de Voordelta te vrijwaarden van visserij: op 43, 50 en $100 \mathrm{~m}$ van de omtrek van het oesterbank. Ervan uitgaande dat het rif zich mogelijk nog zal uitbreiden in de toekomst, bevelen we aan een ruime bufferzone aan te houden van $100 \mathrm{~m}$. Indien de wens is alleen het bestaande rif minimaal te beschermen, dan is $43 \mathrm{~m}$ het minimum.

Van deze bufferzones zijn vereenvoudigde versies gemaakt omwille van het beheer. We bevelen de vereenvoudigde omgrenzing aan te houden als dit handig is voor het beheer. 


\section{$5 \quad$ Kwaliteitsborging}

Wageningen Marine Research beschikt over een ISO 9001:2015 gecertificeerd kwaliteitsmanagementsysteem. Dit certificaat is geldig tot 15 december 2021. De organisatie is gecertificeerd sinds 27 februari 2001. De certificering is uitgevoerd door DNV GL.

Indien sprake is van onbeheerste kwaliteit worden passende maatregelen genomen. 


\section{Literatuur}

Bos, O. G., \& Tamis, J. E. (2020). Evaluatie van OSPAR aanbevelingen voor bedreigde en / of achteruitgaande soorten en habitats in Nederland (Wageningen Marine Research rapport C006/20NL). Wageningen Marine Research. https://doi.org/10.18174/512835

Christianen, M. J. A., Lengkeek, W., Bergsma, J. H., Coolen, J. W. P., Didderen, K., Dorenbosch, M., Driessen, F. M. F., Kamermans, P., Reuchlin-Hugenholtz, E., Sas, H., Smaal, A., van den Wijngaard, K. A., \& van der Have, T. M. (2018). Return of the native facilitated by the invasive? Population composition, substrate preferences and epibenthic species richness of a recently discovered shellfish reef with native European flat oysters (Ostrea edulis) in the North Sea. Marine Biology Research, 14(6), 590-597. https://doi.org/10.1080/17451000.2018.1498520

Couperus, A. S., Aarts, G., Van Giels, J., De Haan, D., \& Van Keeken, O. (2009). Rapport onderzoek naar bijvangst bruinvissen in de Nederlandse visserij.

Didderen, K., Lengkeek, W., Kamermans, P., Deden, B., \& Reuchlin-Hugenholtz, E. (2019). Pilot to actively restore native oyster reefs in the North Sea Comprehensive report to share lessons learned in 2018. Report 19-013. Bureau Waardenburg. https://www.ark.eu/sites/default/files/media/Schelpdierbanken/Report_Borkumse_Stenen.pdf

EC. (2011). UITVOERINGSVERORDENING (EU) Nr. 404/2011 VAN DE COMMISSIE van 8 april 2011 houdende bepalingen voor de uitvoering van Verordening (EG) nr. 1224/2009 van de Raad tot vaststelling van een communautaire controleregeling die de naleving van de regels van het. Publicatieblad van de Europese Unie, 404. https://eur-lex.europa.eu/legalcontent/NL/TXT/PDF/?uri=CELEX: 32011R0404\&qid =1609945224215\&from =EN

Eigaard, O. R., Bastardie, F., Breen, M., Dinesen, G. E., Hintzen, N. T., Laffargue, P., Mortensen, L. O., Nielsen, J. R., Nilsson, H. C., O’Neill, F. G., Polet, H., Reid, D. G., Sala, A., Sköld, M., Smith, C., Sørensen, T. K., Tully, O., Zengin, M., \& Rijnsdorp, A. D. (2016). Estimating seabed pressure from demersal trawls, seines, and dredges based on gear design and dimensions. ICES Journal of Marine Science: Journal Du Conseil, 73(suppl 1), i27-i43. https://doi.org/10.1093/icesjms/fsv099

Eigaard, O. R., Bastardie, F., Breen, M., Dinesen, G. E., Hintzen, N. T., Laffargue, P., Mortensen, L. O., Rasmus Nielsen, J., Nilsson, H., O’Neill, F. G., Polet, H., Reid, D. G., Sala, A., Sköld, M., Smith, C., Sørensen, T. K., Tully, O., Zengin, M., \& Rijnsdorp, A. D. (2016). A correction to "Estimating seabed pressure from demersal trawls, seines and dredges based on gear design and dimensions" †. ICES Journal of Marine Science, 73(9), 2420-2423. http://dx.doi.org/10.1093/icesjms/fsw116

Have, T. M. Van Der, Jagt, H. Van Der, Kamermans, P., \& Sas, H. (2019). Biogene riffen in de Voordelta. Verspreiding en verkenning van verklarende factoren (No. 19-052). Bureau Waardenburg bv. https://edepot.wur.nl/521472

Kamermans, P., \& Smaal, A. (2009). Evaluatie van de mosselzaadinvang ( MZI ) proefperiode 2008 (C022/09). Wageningen IMARES Institute for Marine Resources \& Ecosystem Studies. https://library.wur.nl/WebQuery/wurpubs/fulltext/3508

Kamermans, P., \& Smaal, A. (2014). Passende Beoordeling (PB) mosselzaadinvang (MZI) op vrije gronden in de Nederlandse kustwateren voor de periode 2015-2018 (C168/14). IMARES Wageningen UR.

Kamermans, P., Lengkeek, W., van der Have, T., Sas, H., \& Smaal, A. C. (2016). Presentatie: Herstel Platte Oester op de Noordzee: Vooronderzoek schelpdierpilotlocaties Voordelta. IMARES, Sascon, Bureau Waardenburg. http://library.wur.nl/WebQuery/wurpubs/fulltext/380164

Kamermans, P., Smit, C., Wijsman, J., \& Smaal, A. (2014). Meerjarige effect- en productiemetingen aan MZI's in de Westelijke Waddenzee, Oosterschelde en Voordelta: samenvattend eindrapport (C191/13). IMARES Wageningen UR. https://edepot.wur.nl/312852

LNV. (2008). Toegangsbeperkingsbesluit Bodembeschermingsgebied Voordelta dd 9-06-2008 DRZ2008-2213-1

(http://www.maasvlakte2.com/kennisbank/Toegangsbeperkingsbesluit\%20bodembeschermingsge bied\%20Voordelta.pdf). 
Min LNV. (2020). Beleid voor mosselzaadinvanginstallaties (MZI's) 2021 t/m 2026.

https://www.rijksoverheid.nl/documenten/beleidsnotas/2020/11/30/beleid-voor-

mosselzaadinvanginstallaties-mzi-s-2021-t-m-2026

Min LNV (2020b). Updated Conservation Plan for the Harbour Porpoise Phocoena phocoena in the Netherlands Maintaining a Favourable Conservation Status. Ministry of Agriculture, Nature and Food Quality. https://www.rijksoverheid.nl/documenten/rapporten/2020/11/16/updatedconservation-plan-for-the-harbour-porpoise-phocoena-phocoenain-the-netherlands

Min. IenM, RWS Zee en Delta (2016). Natura 2000 Voordelta 2015-2021. Beheerplan, februari 2016.

MinEZ. (2016). Besluit van de Staatssecretaris van Economische Zaken van 25 oktober 2016, kenmerk 16150944 , tot wijziging van de (beperking in) toegankelijkheid van enkele gebiedsdelen ex artikel 20 Natuurbeschermingswet 1998, gelegen binnen het Natura 2000 gebied 'Voor. Staatscourant, $57780,1-13$. https://www.rwsnatura2000.nl/gebieden/voordelta/vd_documenten/default.aspx\#folder=343212

MinI\&W, \& MinLNV. (2018). Mariene Strategie (deel 1) 2018-2024: actualisatie van huidige milieutoestand, goede milieutoestand, milieudoelen en indicatoren. Waterstaat, Ministerie van Infrastructuur en Ministerie van Landbouw Natuur en Voedselkwaliteit,.

N2K Group. (2018). Review of fisheries management measures in Natura 2000 sites (Issue April). N2K Group. https://ec.europa.eu/environment/nature/natura2000/marine/docs/Review of fisheries management measures in Natura 2000 sites.pdf

Nordheim, H. von, \& Wollny-Goerke, K. (eds.) (2016). 4th International Conference on Progress in Marine Conservation in Europe 2015. Proceedings of the Conference Stralsund, Germany, 14 - 18 September 2015. In Natur und Landschaft : Zeitschrift für Naturschutz und Landschaftspflege (BfN-Skripten 451; Vol. 91, Issue 1). BfN. https://www.bfn.de/fileadmin/BfN/service/Dokumente/skripten/Skript451.pdf

OSPAR Commission. (2008). List of Threatened and/or Declining Species and Habitats (OSPAR Agreement 2008-06). https://www.ospar.org/documents?d=32794

OSPAR Commission. (2013). OSPAR Recommendation 2013/4 on furthering the protection and conservation of Ostrea edulis in Region II of the OSPAR maritime area and Ostrea edulis beds in Regions II, III and IV of the OSPAR maritime area. OSPAR(2) 13/4/1, Annex 7. https://www.ospar.org/documents?d=32968

Poot, M. J. M., Schouten, P., Hogenstein, L., Schoten, H. ., \& den Held, A. (2006). Passende beoordeling huidig en toekomstig gebruik in Natura 2000-gebid voordelta (rapport nr. 06-111). Bureau Waardenburg bv. https://api.commissiemer.nl/docs/mer/p18/p1827/1827-08pb.pdf

Rijnsdorp, A. D., Bastardie, F., Bolam, S. G., Buhl-Mortensen, L., Eigaard, O. R., Hamon, K. G., Hiddink, J. G., Hintzen, N. T., Ivanović, A., Kenny, A., Laffargue, P., Nielsen, J. R., O’Neill, F. G., Piet, G. J., Polet, H., Sala, A., Smith, C., van Denderen, P. D., van Kooten, T., \& Zengin, M. (2016). Towards a framework for the quantitative assessment of trawling impact on the seabed and benthic ecosystem. ICES Journal of Marine Science: Journal Du Conseil, 73(suppl 1), i127i138. https://doi.org/10.1093/icesjms/fsv207

Rijnsdorp, A. D., Bos, O. G., \& Slijkerman, D. M. E. (2015). Impact Assessment of the Flyshoot fishery in Natura 2000 and MSFD areas of the Dutch continental shelf (http://edepot.wur.nl/365972). IMARES. http://edepot.wur.nl/365972

Rijnsdorp, A. D., Stralen, M. Van, Baars, D., Hal, R. Van, Jansen, H., Leopold, M., Schippers, P., \& Winter, E. (2006). Rapport Inpassing Visserijactiviteiten Compensatiegebied MV2. Rapport Wageningen Imares (C047/06). Wageningen IMARES Institute for Marine Resources \& Ecosystem Studies. http://edepot.wur.nl/151274

Röckmann, C., Lelij, A. C. van der, Duren, L. van, \& Steenbergen, J. (2015). VisRisc - risicoschatting medegebruik visserij in windparken (C138/15 A). IMARES Wageningen UR, Deltares. http://library.wur.nl/WebQuery/wurpubs/fulltext/360260

Roozen, F., \& Fellinger, M. (2005). Verkenning effecten van visserij op Ensis en Spisula in VHRgebieden. Inventarisatie van gegevens ten behoeve van de behandeling van vergunningaanvragen voor visserij op Halfgeknotte strandschelpen (Spisula) en Mesheften (Ensis) in de VHR-gebieden Voordel (EC-LNV nr. 2005/356 Ede,). Expertisecentrum LNV. https://edepot.wur.nl/145229

RVO. (2020). Informatiebulletin Visserij december 2020. RVO-192-2020/BR-DUZA De (Issue december). Rijksdienst voor Ondernemend Nederland. https://www.rijksoverheid.nl/documenten/brochures/2021/01/05/informatiebulletin-visserijdecember-2020 
Sas, H., Didderen, K., Van Der Have, T., Kamermans, P., Van Den Wijngaard, K., \& Reuchlin, E. (2019). Recommendations for flat oyster restoration in the North Sea. Sas Consultancy, Bureau Waardenburg, Wageningen Marine Research.

https://www.ark.eu/sites/default/files/media/Schelpdierbanken/Recommendations_for_flat_oyster _restoration_in_the_North_Sea.pdf

Sas, H., Kamermans, P., Have, T. van der, Lengkeek, W., \& Smaal, A. (2016). Shellfish reef restoration pilots Voordelta. Annual report 2016. 20-12-2016. Sas Consultancy, Bureau Waardenburg, Wageningen Marine Research. https://edepot.wur.nl/405730

Sas, H., Kamermans, P., Van der Have, T. M., Christianen, M. J. A., Coolen, J. W. P., Lengkeek, W., Didderen, K., Driessen, F., Bergsma, J., Van Dalen, P., Van Gool, A., Van der Pool, J., \& Van der Weide, B. (2017). Shellfish bed restoration pilots Voordelta, The Netherlands. Annual report 2017, 30-03-2018. Sascon, Wageningen Marine Research, Bureau Waardenburg. https://edepot.wur.nl/467084

Savina, E., Krag, L. A., \& Madsen, N. (2018). Developing and testing a computer vision method to quantify 3D movements of bottom-set gillnets on the seabed. ICES Journal of Marine Science, 75(2), 814-824. https://doi.org/10.1093/icesjms/fsx194

Tamis, A. J. E., Wal, J. T. Van Der, \& Bos, O. G. (2017). Quickscan potentiële natuurwaarden in bestaande Nederlandse offshorewindparken (C025/17). Wageningen Marine Research (University \& Research Centre). https://edepot.wur.nl/411385

Troost, K., Asch, M. Van, Brummelhuis, E., Ende, D. Van Den, Es, Y. Van, Perdon, K. J., \& Pool, J. Van Der. (2021). Centrum voor Visserijonderzoek ( CVO) Schelpdierbestanden in de Nederlandse kustzone, (CVO rapport 21.001). Stichting Wageningen Research Centrum voor Visserijonderzoek (CVO). https://edepot.wur.nl/538895

Vaste commissie voor Landbouw, Natuur en Voedselkwaliteit (2020). Verslag van een algemeen overleg van 12 oktober 2020 van de vaste commissie voor LNV met de Minister van LNV. Tweede Kamer, vergaderjaar 2020-2021, 33 450, nr. 78. Mariene Strategie voor het Nederlandse deel van de Noordzee (Issue 78, pp. 1-54). https://zoek.officielebekendmakingen.nl/kst-33450-78.pdf

Witbaard, R., Kamermans, P., \& Bos, O. G. (2020). "Age" determination of Oysters from the Voordelta reef (No. 2020-01). NIOZ. https://dx.doi.org/10.25850/nioz/7b.b.y. 


\section{Verantwoording}

Rapport C040/21

Projectnummer: 4318100323

Dit rapport is met grote zorgvuldigheid tot stand gekomen. De wetenschappelijke kwaliteit is intern getoetst door een collega-onderzoeker en het verantwoordelijk lid van het managementteam van Wageningen Marine Research

Akkoord:

P. Kamermans

onderzoeker

Handtekening:

Datum:

12 april 2021

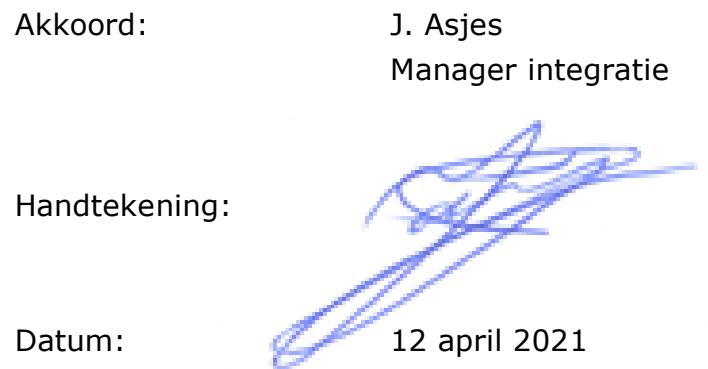


Wageningen Marine Research

T: $+31(0) 317480900$

E: marine-research@wur.nl

www.wur.nl/marine-research

Bezoekers adres:

- Ankerpark 271781 AG Den Helder

- Korringaweg 7, 4401 NT Yerseke

- Haringkade 1, 1976 CP IJmuiden
Wageningen Marine Research levert met kennis, onafhankelijk wetenschappelijk onderzoek en advies een wezenlijke bijdrage aan een duurzamer, zorgvuldiger beheer, gebruik en bescherming van de natuurlijke rijkdommen in zee-, kust- en zoetwatergebieden.
Wageningen Marine Research is onderdeel van Wageningen University \& Research. Wageningen University \& Research is het samenwerkingsverband tussen Wageningen University en Stichting Wageningen Research en heeft als missie: 'To explore the potential of nature to improve the quality of life' 